\title{
First Military Prize Essay for Gold Medal Competition
}

\section{Captain J. Markham Rose R.M.A., p.s.c.}

To cite this article: Captain J. Markham Rose R.M.A., p.s.c. (1901) First Military Prize Essay for Gold Medal Competition, Royal United Services Institution. Journal, 45:279, 541-593, DOI: 10.1080/03071840109417597

To link to this article: http://dx.doi.org/10.1080/03071840109417597

册 Published online: 11 Sep 2009.

Submit your article to this journal $\sqsubset \pi$

Џlll Article views: 7

Q View related articles ๘ 


\title{
FIRST MILITARY PRIZE ESSAY FOR
}

\section{GOLD MEDAL COMPETITION.}

\author{
Subject :- \\ "LESSONS TOO BE DERIVED FRON THE EXPEDITION TO \\ SOUTH AFRICA IN REGARD TO THE BEST ORGANISA- \\ 'TION OF THE LAND FORCES OF THE EMPIRE." \\ B) Captain J. MARKHAMT ROSE, R.M.A., p.s.c.
}

"Spero .Mcliora."

INTRODUCTION.

A GREAT Empire engages in a struggle with two small Republics, and discovers with surprise that tardy victory is only to be obtained by straining every sinew in the task. Yet both the difficulty of the conquest and the painfulncss of the surprise have many parallel's in the world's history: Small States, time after time, have retained or recovercd their independence in spite of all the efforts of famous Empires, aided by the nobility of their cause, the courage and skill of their peoples, and difficulties of country not to be overcome by the trained hosts of their opponents based on distant shores. There is, for example, that noble forty years' struggle when the Hollanders wrested their independence from the power of Spain; and now, England, warring against a kindred race, has only emerged successful from the struggle after trembling on the brink of failure. History teaches that in the past, where the small Statc has succeeded, it was generally because the decline and fall of the Empire had commenced, that effeminacy, intrigue, and misgovernment had cankered the heart, and so had weakened the distant arms. Our case is hardly so bad as that, for the issue has demonstrated that the heart of the people is sound cnough, but our approximation to failure has also shown that there is greater need for care and precaution in the future.

The present task is to search for organisation lessons taught by our recent experience. Unhappy is the lot of the essayist who is bidden to search for "lessons," for his very aim bids him pass lightly over the successful part and only dwcll where a sjstem has failed. It is his fate, 
and may not be avoided; yet he cannot but think reluctantly of the patient energy and glowing decds which he would feign describe.

Older military history again helps in the arrangement of the work. These struggles on the outposts of Empires have mainly arranged themselves into three phases-the first, where the lesser antagonist has everything very much his own way because he has merely to contend with a peace garrison or an outpost; the second, when the outposts reinforced have to check the wave of success whilst preparations are being made for the Empire to re-assert itself in the third. Such a process, with some modification in each case, particularly applics to most of our wars overseas, as, for example, the Indian Mutiny, Egypt (1882), and, in an extended way, to the Soudan struggle as a whole.

In the present case, then, the three phases of the war in South Africa may be said to be:-

1. The Bocr invasion up to the middle of November, 1899, including the mobilisation and arrival of the first troops of the army corps.

2. From the middle of Novenber to the arrival of Lord Roberts in South Africa.

3. The re-assertion of empire in the rest of the war.

As it is bejond the subject to deal with the history of the war, and also as most of its events are still fresh in the minds of all, the different periods will generally only be referred to in so far as they deal with organisation. At.the same time, since dates and numbers are apt to be elusive and may have a direct bearing on the question, they will often be given. It is unfortunate that up to the present no authoritative statement can yet prove many of them to be reliable, so they must be accepted with a limited confidence, and, indeed, it is quite possible that we shall never know the real facts of the details of Boer organisation and equipment.

\section{The First Phase.}

The estimate published by the Press immediately before the war put the Boer strength sor.ewhat as follows:-

\begin{tabular}{|c|c|c|c|c|c|c|}
\hline \multicolumn{5}{|c|}{ State, etc. } & Numbers. & \multirow{2}{*}{$\begin{array}{c}\text { Guns. } \\
60\end{array}$} \\
\hline Transvaal & - & - & - & - & 30,000 & \\
\hline Free State. & - & - & & - & 20,000 & 10 \\
\hline Cape Colony & and $N$ & Vatal & Boers & - & 5,000 & 一 \\
\hline Forcign con & ngent & & - & - & 5,000 & - \\
\hline & lot & - & - & - & 60,000 & 100 \\
\hline
\end{tabular}

1 Will reillers in criticising this Fsing also kindly remember the following "extenuating circurnstances" due to the fact that the Essing hand necessarily to be written in the autumn of 1900 ? First :-At that time the only information about crents in Sostlt Africi liad to be obtaincel from newspaper reports which had pan-eyl through the latuls of the l'ress Censor. Second :-A great number of my idess now

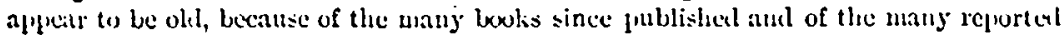
enreches buth in aud out of larliament bearing on the ame subject.-J. J. I. 
The estimate of guns is probably too low, and does not include the lighter Q.F. guns, and docs not explain the excellent effects obtained by their weapons, which were of the very latest desigu. Other estimates at times have placed the numbers of men as hinh as 100,000 ; but it is extremely difficult to know where they could have rome from. The real Transvaal and Free State Boers cannot have exceeded the numbers given above, though it seems probable that the numbers of the Afrikanders from the Cape Colony and Natal and the foreign contingents were considerably exceeded when the Boer invasion was at its flood. Indeed, it is fairly certain that the Bocr forces never excecded 75,000, of whom a minute portion, the Stats artillery, etc., were regular soldiers, the remainder being merely farmers and city population gathered together by" the "commandeering" systcm, plus the unknown contingent of foreign mercenaries and volunteers from European States, and rebels from our own Government, all inspired with the hope of driving the British from South Africa.

To this ill-organised and ill-trained but excellent fighting force what had we to oppose? The troops in garrison in South. Africa before the war were distributed as follows:-

\begin{tabular}{|c|c|c|c|c|c|c|c|}
\hline- & & & Infantry. & Caraliy. & Artillery. & Guns. & IR.F. \\
\hline $\begin{array}{l}\text { Cape Colony } \\
\text { Siatil } \quad \ldots\end{array}$ & $\begin{array}{l}\ldots \\
\ldots\end{array}$ & $\begin{array}{l}. . \\
. .\end{array}$ & $\begin{array}{l}2,800 \\
2,400\end{array}$ & $i \overrightarrow{00}$ & $\begin{array}{l}300 \\
\quad 5.50\end{array}$ & $\overline{22}$ & 200 \\
\hline
\end{tabular}

or about 7,000 men with 22 guns. About the middle of September, 1899, this strength was increased by about $2,000 \mathrm{men}$, or say, with the addition of the Colonial police, some 10,000 men, to garrison all the important railway junctions and depòts of supply. Yet, before this quite inadequate number was again added to, in the beginning of October, the Boers were already mobilising on the frontier; and double the strength could not have prevented the invasion of our territory by so mobile a foe. However, on the 7 th September, the Government had sanctioned a reinforcement of 10,000 men to be despatched at once. For our purpose, it is interesting to learn where this large number of tronps was to come from. Unless we called the Reservists to the ranks, our units at home were not prepared for war-they were merely a machinery fortraining recruits and to supply drafts for their linked units abroad. A large proportion of their rank and file were boy's under twenty jears of age, unfit for service abroad; and to take these units at this period yould only be to hamper our mobilisation system later on.

At this date, 7th September, the units of our Regular Army were disposed as follows :-

'This is only fighting strength, for a Parliamentary Return shows on Ist August, 1899:-Caralry, 1,127 ; artillery, 1,035; infantryanl mounted infantry, 6,428 : others, $1,032-$ total, 9,622 . 


\begin{tabular}{|c|c|c|c|c|c|c|}
\hline Arm and Unit. & & At Home. & India. & $\begin{array}{l}\text { Sonth } \\
\text { Africa. }\end{array}$ & Abroad. & Total. \\
\hline $\begin{array}{l}\text { Cavalry regiments } \\
\text { R.Il.A. batteries } \\
\text { R.F.A. batteries } \\
\text { Infantry battalions }\end{array}$ & $\begin{array}{l}\cdots \\
\cdots \\
\cdots \\
\cdots\end{array}$ & $\begin{array}{l}16 \\
10 \\
18 \\
7: 5\end{array}$ & $\begin{array}{r}9 \\
11 \\
42 \\
52\end{array}$ & $-\begin{array}{l}2 \\
3 \\
0 !\end{array}$ & $-{ }_{101}^{1}$ & $\begin{array}{l}28 \text { regta. } \\
21 \text { R.H.A. } \\
91 \text { R.F.A. } \\
\text { 1:3 bns. }\end{array}$ \\
\hline Totals in men & ... & $10 t, 500$ & $7 \pi, 000$ & 19,000 & 31,000 & 224,500 \\
\hline
\end{tabular}

These approximate totals include Royal Engineers, departments, coast defence, and mountain artillery.

The force at home was detailed, with 81,000 Reservists called in, to provide us with three army corps and four cavalry brigades for home defence; or two army corps, a cavaly division, and line of communication troops (about 80,000 men), for service abroad.

As it was not desirable to dislocate the labour market and spoil our main system by a partial mobilisation, another solution of this first difficulty was found. Units in India and in the Mediterranean and Egypt are practically ready for war service at any time, and the 10,0100 was made up from these places. Not that these garrisons are normally: one man in excess of even peace requirements for moderate security, but there were great apparent advantages for the reasons just given, and because units so called on could more rapidly reach the threatened points than troops from home.

From India we took 5,800 out of 75,000 , leaving only 70,000 British, the minimum proportion laid down to help the 140,000 native troops to guard our great possession in the East; but these reinforcements were seasoned men, and could reach Natal a week earlier than from home. (The actual units, with dates of arrival, are given in $\Lambda$ ppendix No. I.) Nearly half of these had actually arrived, and the rest were arriving when war was declared on 11th October.

At the same period, too, as the authorisation of the reinforcements from India, permi, sion had been given to raise a body of Imperial Light Horse at Durban, mainly recruited from and officered by Uitlanders. This corps was rapidly placed in a state of efficiency, and. was the forerunner of many other Volunteer cerps raised in South Africa. (See Appendix II.) Previously, Colonel Baden-Powell had been organising police and local troops for the defence of Mafeking, and, aided by Lieut.-Colonel Plumer, had organised a force in Rhodesia to observe the northern frontier of the Transval in the Buluwayo direction.

From 21st September the .Natal frontier, was watched by armed Boers, and quiet preparations in the Free State made war appear unavoidable, and that with both Republics at once, not to mention insurgents from our two self-governing Colonies.

Therefore, on 27th September, 25 companies of the Army Service Corps had been placed under orders for the Cape, sailing about 7th 
October. At this period, too, the I'ransport Department at the Admiralty were rapidly taking up ships for transport purposes; Woolwich Dockyard and all the great centres for military stores were working double tides ; and transport animals, principally mules, were being bought up in large numbers in Spain, Italy, and America. All these were supposed to be merely precautionary measures, but the Press of the whole world was busily engaged in describing what we were doing. Machinery which works so noisily should surcly be capable of improvement! Yet there are few who realise how vast this question of the preparation of transport is. A single battalion, on the Natal side of the theatre at any rate, had the following regimental transport:-

1 Maxim gun, drawn by 2 mules, with 2 spare - 4 mules.

1 Scotch cart (as used in South Africa) for tools - 6 ",

4 S.A.A. car's, at 6 mulès each - - - - 24 "

1 Water-cart for cooking-water only - - - 4 ,"

7 Cape wagons, at 14 oxen each - - - $\quad 98$ oxen.

14 Vehicles - - - - - 136 animals.

Thousands of the Scotch carts and ox-wagons had to be made at home on the South African pattern. Later on, too, traction-engines were sent out, originally intended for the siege-train, but mainly used for ordinary transport purposes wherever roads were available, since they could drag 10 to 12 tons, while the ox-wagons could only take 2 tons. The ox-wagon had the further disadvantage of being 20 feet long, and, with its 14 oxen, occupying 260 yards in column of route. No food could be carried for the oxen, and the $y^{i}$ had to be turned out to graze. and thousands of them died. They could only do about 15 miles in a day's march, and greatly hampered our movements by their slowness. It is easy to comprehend with such transport how the Natal force train column is reported to have occupied 25 miles in column of route. The transport of each battalion would occupy nearly a mile, to which must be added brigade, divisional, and corps reserves of food and ammunition, and all the hospital arrangements. A supply park alone should take 300 tons of food; a battalion takes 6,000 lbs. of ammunition, while an ammunition park has 130 tons?

What work all this must involve in the theatre of operations, and how much care and foresight at home before the real fighting can commence! The task of Woolwich Arsenal in providing and carrying out the ammunition supply can be better imagined than described. A rejection of the Mark $I V$. bullet in consequence of the decision of the Peace Conference helped to complicate their task. - The pressure was extreme, and it is a matter of the highest credit that not only was the Arsenal able to meet this first demand, but also to keep the Army supplied to the end of the war, but this only by the strenuous labours of 20,000 men working literally night and daj. Greater reserves of stores, provided in time of peace, might have greatly lightened this strain, and would have, in the lnog run, tended to greater economy. But, on the other hand, many 
stores were only applicable to this campaign, and would be useless for any other country. Still, the strain would undoubtedly be relicved in the future by the creation of another arsensal in the North of England. And as regards transport, another thing is certain, our Army Service Corps was not nearly large cnough for the work required of it, as had been clearly demonstrated by the Salisbury Plain mancuvres of the year before. The 38 companies before the war are now to be increased to 88 it is said, and these will be none too many. Of the provision of ships and animals more will be said in another place.

By 5th October the Boers had assembled strong commandoes along all their frontiers, eagerly awaiting the order to invade, with strong reserves at Pretoria and Bloemfontein. In short, the Transvaal mobilisation was practically complete as regards men, but they had still some work to do in or janising their transport and other details; probably the Free State was not quite ready at this date, and the enemy was also waiting for the first rains before declaring war.

On our side, as a result of the previous measures, from 2 nd October onwards the 10,000 reinforcemeht was arriving daily, and Natal appeared to be fairly safe; Mafeking and Kimberley were in some sort prepared for a siege, due greatly to individual initiative. Our limited garrisons were reinforced also by small naval brigades, the Adiniralty having made a brilliant move in arranging the meeting of the "Terrible" and "Powerful" on the Cape Station, which shows how sea power may be utilised in such an emergency.

The actual disposition of our troops in the beginning of October is given in Appendix III.

Thousands of tons of stores were being collected in the advanced depôt at De Aar, which was but feebly defended, and matters were felt to be so advanced that on 7 th October the order for mobilising the 1st Army Corps was issued. The declaration of war came on the 11th, followed immediately by the invasion of Natal by some 25,000 to 30,000 combined Free State and Tranivaal Bocrs, firmly believing that they would sweep us into the sea. They so far succeeded that before the first troops of our army corps arrived in the middle of November, Sir George W'hite and the inain portion of the Natal troops were securely invested in Ladysmith, and the whole of the Colony to the north of that place was in the possession of the Boers. Further, wc had cvacuated Colenso and withdrawn to Estcourt, 27 miles further south; Durban was merely defended by a Naval Brigade and hastily raised Colonial Volunteer corps. In other words, between the Boèrs and Durban there were only about 3,000 of these Colonial troops, two Regular battalions, and a small naval force.

Nor was the situation more farourable on the other side of the theatre. On 13th October the Bocrs had commenced the famous siege of Mafeking with some $\overline{5}, 000$ men under Cronje, while Baden-Powell's levy certainly did not exceed 1,200 men, and he had no guns worthy of the name. No places south of IIafeking were being held for the Empire until Kimberley was reached, and that town had also been isolated since the beginning. of November by 10,000 Boers who had pushed advanced 
posts to the line of the Orange River. Kimberley was only held by half a Regular battalion, a few Royal Artillery and Police, local Volunteers, and the Town Guard. Noreover, on 1st November the commandoes on the south of the Free State crossed the Orange River, having lost their fear of the Basutos, and advanced to Stormberg Junction, which they occupied, our small garrisòn bèing withdrawn without fighting. Similarly; the garrison of Naauwpoort was withdrawn to the dangerously exposed depót at De Aar. In addition to the Regular troops shown in the table, and the isolated garrisons, we had on this side about 2,000 Cape MIounted Police, 1,000 Cape Mounted Rifles, and 4,000 Cape Volunteers. Nany more Cape troops were afterwards raised; but at this period the Cape Colony administration was not at all keen in its assistance. In all the districts conquered by the Boers commandecring went on, many rebels ioined them voluntarily, and the commandoes increased daily.

Hence, turn where one would in South Africa, the aspect of affairs was not at all favourable to the ultimate success of British arms, but the history of war shows that this gloomy outlook is part and parcel of the first phase. In our own history we seem always to have been on the point of failure, and have only redeemed our character not 50 much by careful organisation as by the peculiar doggedness of the race. Things were really now far worse than at Christmas time, but the people at home were quite cheerful, even joyful, for was not our precious army corps and its brilliant cavalry division on the way out, not only to wipe out all memory of present reverses, but also of MIajuba!

In our own case, can this general state of affairs on the outbreal of trouble at the outposts of the Empire be avoided? It is evidently impracticable to maintain peace garrisons throughout the Empire strong enough to prevent a sudden invasion; but is it possible to devise means by which a point immediately threatened can be strengthened rapidly enough to repel the first onslaught, and so gain time for full reinforcements? Let us consider what different steps might be taken.

We have always been greatly aided in this part of our struggles by the voluntary efforts of British residents of the part attacked, and this war has given us fresh examples of this. Natal Voluntecrs and the Kimberley and Mafeking townspeople made resistance possible where the Regular troops unaided would have been at once overpowered. Is a solution of the question to be found in a development of this? 'There are already many Nilitia or Voluntecr corps on our outposts, and by greater encouragement and with fuller equipment and organisation they, at any rate, would lessen the difficulty. Will not the Empire in Council put these corps in a more satisfactory position for the safety of the whole? Yet white population is wont to be scattered in such districts, and many do not care to train in time of peace, and are consequently not of much use on the outbreak of war. There is, of course, the ancient custom of every warlike race by which every man can be called on to defend his homestead, and therefore to train in time of peace for such an emergency; but coinpulsory service in these frontier corps could not be logically carried out without conscription throughout the Empire, and even so, 
these scattered troops would not suffice to stop anything greater than a mere raid.

Can the maritime forces of the Empire aid? We know of naval brigades in nearly all our wars. We find Alexandria in 1882 policed by the Bluejackets and Marines; we find in an hour of similar stress that Ladysmith is provided with heavy guns and I)urban held by the fleet, and Admiral Seymour in China has just marched to the relief of the Embassies. Is this naval solution a better one, or is it a correct use of sea power? It is extremely doubtful. Nust the first attack on the outposts of Empire be repelled by the admiral of the station, who is to lay up his ships and land their crews and guns 'till the Army arrives? However correct such a solution, it is only phssible where we have undeubted and unchallenged command of the sea, and even then it is both expensive and dangerous. The seaman-gunner is a very costly article, neither easily nor rapidly replaced, and, with every respect to his valour and efficiency, not sufficiently highly trained for shore fighting in proportion to his cost. Why should he be? He has enougli of other work, in all conscience, to take the full ability of the best of men. What would have happened in Egypt if the French had suddenly placed a hostile fleet off Alexandria? Would a second battle of the Nile have resulted from this Imperial system ? One cannot say, and probably this is an easily combatted suggestion by the adrocates of the system, who would say that we should at least have had sufficient warning to move the crews back to their ships; but Alexandria would have been unpoliced, and, at least, it shows a source of danger. With Admiral Seymour cut off from Tientsin, our fleet was scarcely well placed for the possible, though improbable, case of the hostile combination of the other fleets against us.

Sir John Colomb has a variant of this plan, which seems to have much in its avour, that there should be depots of Narines or soldiers under Admiralty control at all our coaling stations, who would be immediately availabie for the admiral's disposal without weakening his ships, and which, while being of use to the Empire in this first phase of our wars, would also be invaluable in naval wars as reinforcements to the ships after a battle.

Both this and the frontier force schemes are worthy of attention, but the real solution can only coine from rapid mobilisation of military force and efficient Imperial organisation. To attempt to be strong everywhere on an almost boundless frontier line like ours is to end by being weak everywhere. The strength must lie towards the centre, but so held there that it can be rapidly moved to the threatened point. Then, given a sufficiency of the central force and a smoothness of organisation, the outpost, even though carried, will be rapidly recaptured, and war pushed across the frontier to the hostile territory. Did our mobilisation in the present case fulfil these conditions?

Although many of the details of the despatch of the 1st Army Corps must be of common knowledge to military readers, yet the essay would be scarcely complete without a slight summary of them. 'The 
order for the mobilisation of the army corps was issued on 7 th October, and the last day for Reservists to join was the 17th of the same month. The 1st Division sailed on 20th and 21st October, giving fourtecn days for the completion of its mobilisation. This is a long period, compared with Prussian or French ideas; but, on the other hand, the problem set us is different in its main particulars. We had to provide good and rapid transport for a long voyage, and to collect food and land transport 6,000 miles over seas, instead of having our magazines formed in peace and being ready to move to the front at once. It was simply an essential of our scheme that the 25 companies of Army Service Corps had been despatched a fortnight earlier, and that the period of embarkation of the whole extended to a fortnight later than the day mentioned for the assembly of the fighting units. Yet, even so, that it should take us a whole month in which to despatch one army corps and a cavalry division (and five weeks for the line of communication troops) is a matter for careful examination; and we shall probably find that, based on the present experience and with careful organisation, we shall be able to shorten the period. Morcover, it was wcll into November before certain scattered units were despatched, partly, but not invariably, delayed by unavoidable accident. These were troops despatched to flourishing Colonies, where the collection of stores and formation of magazines would be simple as compared with an expedition having its base over seas and actually in the hostile territory. Yet these Colonies were able to supply very little themselves, and all had to be collected either at home or in distant countries, and then moved by sea-transport in long-voyage ships to the magazines in South Africa.

This item of ships was one that no other Power could have contended with in anything like the same period of time. For the men alone we took up and employed 60 large transports, averaging nearly 10,000 tons a vessel, belonging as a rule to the first-class lines, and most of which sailed within the fortnight from 20th October, followed immediately, between the 11 th and 16 th November, by four more, taking 3 battalions and a mountain battery to replace casualties at Nicholson's Nek. Such a fleet does not sail under the flag of any other Power, and this total does not include the many ships sailing at this very time with horses, mules, and supplies from Home, Australia, India, Naples, Sicily, Cartlagena, New Orleans, and other places, nor the ships taking the Army Service Corps, and the usual South African lines, which had been carrying, and continued to carry, large quantities of men and supplies during the whole operations. For the South African war of 1878 we took up 10 transports; 47 for the Egsptian campaign of 1882 ; and for the present war nearly 200, and, on the whole, Jarger and better found than in the previous instances. Yet our ocean trade was scarcely dislocated, and the price of wheat, a true measure of the dislocation, only rose some $2 \mathrm{~s}$. a quarter-from $25 \mathrm{~s}$. to $27 \mathrm{~s}$., or $10 \mathrm{~s}$. less than its price during the Spanish-American war:

The actual rapid and careful fitting of the ships as transports has always presented great difficulties, and we seem to have made steady 
progress in this matter, though horse-fittings are still capable of improvement. Agnin, the actual lading is a matter for careful organisation and in which we have had vast experience; from which; on the whole, we have profited. There were none of the ghastly errors of the Crimea, though, as appears to be incvitable, there were minor mistakes; and contractors do not secm to have been invariably honest, and inspectors of stores in the extreme pressure of work have by neglect connived at the embarkation of inferior quality of supplies.

It must always be a great question whether battalion transport should accompany the unit, for it amounts to a very large total in horses and vehicles, and ships quite ready to carry infantry alone have to be delayed while being properly fitted. Yet a battalion without its transport is to a great extent immobile, and, therefore, in most cases to take it seems most praćicicable.

It is undoubtedly the soundest policy, and in the long run the cheapest, to take up the most modern, largest, and fastest ships. Less liability to break down, better fittings, quicker transportation, and better condition of troops and horses on arrival are advantages so great as to compensate for much initial increase in cost. That this is one of the lessons of the war there can be no doubt.

Naturally, the length of the royage makes a considerable difference, and three times the number of men could be carried for trips of less than twenty-four hours' duration in the same number of vessels; and then cur national difficulty would be to find the men rather than the ships.

How small our mobilisation was in numbers compared with other nations! We really only despatched about $45,000 \mathrm{men}$, of whom there were under 6,000 cavalry and mounted infantry, and only 19 field batteries, making 96 guns, 18 howitzers, and no guns of position. This is a very small proportion of mounted troops and guns compared with Continental units, and more noticeable still when it had been the Staff College teaching ever since Najuba that mounted infantry was the most desirable arn to contend with the Boers. It is easy enough to be wise after the event, but the subject of our relative weakness in cavalry and guns has for many years been brought forward by the Service members in the annual debates on the Army Estimates; and even with this relative inferiority in mountcd troops we had long been warned that there would be a great scarcity of horses. For the first time we had a practical trial of our system of horse-registration for mobilisation, and large numbers were drawn by this method from omnibus and tramway companies and hunting stables. The value of the system was felt, and the lesson for the future is, that it should be.more largely cxtended.

The approximate strength of the troops mobilised was:-

$\begin{array}{lrrrrr}\text { Units. } & & & \text { Numbers. } & \text { Guns. } \\ 1 \text { cavalry division } & - & - & - & 5,500 & 12 \\ 3 \text { infantry divisions } & - & - & - & 30,000 & 54 \\ \text { Corps troops - } & - & - & 5,000 & 18 \\ \text { Line of communication troops } & - & 11,000 & - \\ & & & -\frac{51,500}{114}\end{array}$


This meant drawing to the ranks some 25,000 Rescrvists, of whom it was most interesting and satisfactory to notice that 98.4 per cent. rejoined promptly, 91 accounted satisfactorily for their absence, and only $1 \cdot 05$ had fitiled to report. 'These figures alone are almost sufficient answer to those critics who, as an argument for a return to a long-service sy-stem, state that the Reserve is merely a paper force not available for war. To the frequently made statement that most of our Reservists are tramps filling the workhouses of the country, the generally respectable and healthy appearancil of the men is sufficient answer. MLost of them caine from r.ally good employment, and it was satisfactory that the Government and most of the employers promised to keep their situations open for them till their return, and in many cases part pay, or an allowance, was made to their families either by the employers or by subscription among the workmen.

This partial mobilisation had no material effect on our railway traffic, and the movement of the men about the country would have been scarcely noticeable but for the enthusiastic crowds who cheered the departure or welcomed the arrival of each batch. Nor was the labour market appreciably affected, though naturally, but unfairly, the most patriotic employers were most hampered by the loss of hands. It seems that to them the country owes some substantial compensation.

Every man of the Royal Scots had come up, and in four other territorial regiments only one man was away.

711 of the Reservists were found unfit for service, not too large a proportion when it is considered that 36.5 per cent. of the men actually serving with the colours were rejected medically unfit or under age, the latter reason accounting for the great part, as none were sent out under 20 years old. This rejection has always been recognised as part of our system, but to have nearly half the ranks of each unit composed of Rescrvists seems too large a proportion, and a long-desired Army Reform is a scheme by which the age of our recruits on joining can be raised. That nearly half the furce mobilised to meet sucl excellent reputed marksmen as the Boers had not been through a course of target practice for two or three years at least, and were, to a great cxtent, unacquainted with the latest developments of the weapon they were to use, was the worst flaw. In the infantry an attempt was made to put these men through a three days' course of musketry. where ranges were available; but this was naturally a somewhat prefunctory affair during such a period of general haste. In other respects, the month which had to elapse before the mobilised units could mect the enemy, gave the Reservists an opportunity of settling down; but this respite would not be obtainable in case of war in Furope.

All the units in this 1st Army Corps were readily made up to war strength as laid down in Field Establishments. Aldershot was the chief centre of mobilisation, and Southampton the chief port of cmbarkation. but the ports of the Thames, Medway, Clyde, and Cork Harbour were also used. For greater rapidity in the future, and for the possible despatch of the larger force suggested, a greater decentralisation is 
required; Southampton, Aldershot, and Woolwich can do no more than their present record without undue congestion. Every commercial port of the Empire should bear its duc share and embark the troops mobilised in its neighbourhood, according to the scheme developed later in the essay.

It was not only in the easy despatch of this expedition that our sea power was evidenced. Although the Transvaal had no Nary, yet the 6,000 miles of sea communications had to be guarded, and the Channel Flect was emplojed for the purpose, and when, later on, practically the whole of our field army was on the seas or over seas, everything was kept in constant readiness for a naval mobilisation, and the Reserve Squadron was assembled-the real danger in this case being, not from the Boers; but from a fossible European embroglio. For this reason the Reserves of Sailors and Marines in the Naval Depoits and Marine Divisions were not available for Service in Sonth Africa, and much heart-burning was caused thereby, yet how much trouble this naval readiness saved us from it is impossible to say.

Finally, before passing on to the second phase, and following Gencral Buller and the army corps over scas, it may here be remarked in answer to certain rabid journalism that at that time practically every Englishman believed that we were sending enough men to settle the matter. Certainly, we argued, Colley had been defeated with six heterogeneous companies; but what are six companies compared with the 60,000 men we should have in South Africa by the end of November? And, again, practically all were agreed that the offers of the Colonies to send contingents, and of our home Volunteers to serve in South Africa, were all very nice and ought to be encouraged, and that was all. There was no feeling that their help was either necessary or even useful. We shall see during the second phase a change pass over the spirit of the people at home.

\section{Second Phase.}

Checking the Isvasion, and Preparation for the Re-assertion of Empire.The practically unchecked successes of the Boers in Natal caused General Buller, on his arrival in South Africa in the beginning of November, to change his plans. This essay has only indirectly to deal with strategy, and the reasons for this change concern the subject very little, but their effect on organisation requires attention. The plan by which each Division would have been landed respectively at Cape Town, Port Elizabeth, and East London, and then advanced northwards on the Orange River by the three distinct railways, not only would have enormously facilitated transport and supply, but would also have maintained, more or less, the army corps organisation. From the moment that General Buller decided to send the first arriving troops to Natal and to proceed thither hinself, the army corps as a unit ceased to exist, and so even did the Divisions. The 1st Division commander, Lord Methuen, 
took the 1st and 3rd Brigades and some other details along the Kimberley line; the 2nd, 4 th, 6 th, and part of the 5 th Brigades went to Natal with Clery, the commander of the 2nd Division; the 3rd Division commander, Gatacre, with a.very small portion of the corps, took over the command of the troops in the Stormberg district. The corps troops were variously distributed, and the Line of Communication troops very rapidly found themselves in the first fighting line. The brigade-division commanders found themselves separated from their distributed batteries; and though General French took a great deal of his Cavalry Division to the command of the Naaunpoort district, yet he had to detach various units to do the mounted work of the other columns. For actual disposition of troops of army corps on landing see Appendix IV.

It is evident that while our higher units are only created on the outbreak of war, and never serve together in peace, there cannot be much object in keeping them together in war if distribution serves our purpose better. We had diligently copied the German or Continental army corps system in our nomenclature, even to the numbering of our brigades and the names of our units, but with that it ended, and from the first landing of our 1st Army Corps, an army corps as a unit did not appear again till the end of the war, although eventually there was a far larger force in the field than ever previously in our history. Bad copies of German systems do not seem to be much of a success for our Imperial needs. The division is still practically the highest British unit which has ever worked as such, and the divisions in. South Africa were rarely the units as mobilised at home; and it seems advisable that until larger units are available for permanent organisation in time of peace, that the division should be the highest unit referred to in any Imperial scheme.

As regards any practical bad results from the splitting up of the mobilised units, in the present instance, they really seem to have been limited to a slight confusion as to the exact address of any particular unit at any particular time, and to resulting confusion in the despatch of some necessaries, and not to have affected the fighting efficiency in the very least. How much greater the fighting efficiency of the force would have been if the divisions had been accustomed to work together in time of peace we can only judge from Continental experience; but that Buller's Natal force gained confidence in their Generals and themselves from their Aldershot work in common, and that the Irish and Lancashire Brigades fought better for their territorial links is universally admitted; while the formation of Guards' and Highland Brigades is a gain in efficiency which has long been admitted; the principle is worthy of a greater cultivation in Imperial organisation.

The transfer of the main transport for the increased force in Natal was a bigger matter, but even for that we were in some sort prepared. It has always been one of the advantages gained by sea-power that the shifting of a base from port to port is amongst the simplest of the important strategical operations of war.

In any case, General Hildyard had assembled the 2nd Brigade at Estcourt by the 22nd November and brought the Boer advance to a 
standstill in Natal ; and when General Clery had also come up, the Boers fell back on their position at Colenso covering the siege of Ladysmith, now being prosecuted with some vigour. Indeed, the town was in some immediate danger of falling, not so much from assault, for the enemy did not shine in such enterprises, but rather from failure of food and ammunition. Disease also was playing. sad havoc with the energies of the-besieged, while General Buller was collecting his forces. By 11th December he had amassed General Dundonald's Cavalry Brigade $(2,600)$, faur brigades of infantry, or about $21,000 \mathrm{men}$, a force especially weak in mounted troops. Only two field batteries per division could be allotted, and there was no proper corps artillery; but there was a mountain battery, two 4.7-inch Q.F., and fourteen 12-pounder Q.F. naval guns; these latter a valuable aid, but not sufficiently mobile. With this force, General Buller commenced the advance, and on 15th December assaulted the Colenso position. He was repulsed with heavy loss, especially in artillery, which he could ill-afford, and the relief of Ladysmith was thus for a time delajed.

In the relief of Kimberley, Lord Methuen had very little better success. His column had been hastily organised for a forward movement, and by the 20th November his advance commenced. After three successful engagements, he was badly repulsed in a night attack at Magersfontein .on 11th December. His force was the weakest of all in cavalry, and never exceeded 11,000 infantry, 850 mounted troops, and 36 guns. The Boers had probably an equal force, and, not being surprised, compelled us to fall back and re-organise in the Modder River position.

With 10th December came General Gatacre's repulse at Stormberg, and the situation as regards the Second Phase was practically complete. There was no great alteration in the relative fronts of the belligerents until after January, 1900, except where General French about Colesberg was doing a little more than holding his own by the restless efforts of his mobile force.

At home people could ill-realise our want of success, and commenced an eager search for a scapegoat on whom to lay the blame. The Government was happily strong enough not to be led away by panic, and to the news of each reverse made a suitable reply in the early despatch of reinforcements. Immediately following the surrender at Nicholson's Nek, three extra battalions, a composite regiment of the Household Cavalry, and another mountain battery, were sent out, and about 35 battalions of Militia were ordered to be embodied by the end of November. As soon as it was known that Ladysmith was invested and Natal in danger of being over-run (7th November), another Infantry Division, the 5th (a 4th Division having been formed in South Africa), and the siege train were mobilised. These troops, under Sir Charles Warren, embarked early; in December, and would arrive at the front before Christmas. A little later, when it became evident that Gencral Buller had had to divide his forces and was scarcely strong enough anywhere for his task, the 6th Division, under Kelly-Kenny, was organised. Before it left, however, came the news of the three repulsed attacts all along the front, and after 
Colenso, on the 16th December, the immediate mobilisation of the 7th Division was ordered to be completed by the 27th Deceinber and to embark with the New Year. Two days later, Lord Roberts was appointed to the supreme command, with Lord Kitchener as Chief of the Staff, and an 8th Division was warned; but we had now touched the limit of our organisation. With the despatch of the 7 th Division we came to the end of the two army corps and Cavalry Division supposed to be ready for service abroad; and the warning of an 8th necessitated the weakening of Colonial garrisons to provide Regular troops for this unit, and these could only be replaced by Militia battalions who.would have to be asked to volunteer for the work as they had done during the Crimea. This call on their patriotism was readily responded to, and more than half the Militia was embodied; and all the Reserve, including Section D, were called out ; but even these constitutional and precedented courses were not equal to the emergency.

The deep feeling at home and general gloom of that Christmas probably went bejond the real occasion, yet had much foundation in the urgent necessities of the immediate situation. It is true that our losses were small as compared with the great wars of history; and although we had been repulsed we had never been routed. We had merely experienced the fact, for many years taught by tacticians, that frontal attacks against good entrenched troops supplied with modern weapons were almost impossible except with vastly superior numbers or with careful artillery preparation; but both the great superiority in numbers and the guns were lacking. It is true that Boer success had invariably ended with the repulse of our attacks; the enemy, however good behind cover, failed equally with ourselves in attack; and matters were merely at a standstill, yet such a standstill meant ultimately Boer victory, for every day of delay brought nearer the fall of our beleaguered towns from starvation and disease, and meant loss of Empire prestige. We were obliged to attack; the Boers were nearly all mounted, and with this power of rapid movement could reinforce any threatened portion of their entrenched lines more quickly and more secretly than we could assemble for assault. If they would not follow up a success, we could not, for lack of cavalry and mounted infantry. Hence more troops, more guns, and more horsemen were urgently required. Now, our Militia system, excellent though it may be, could not supply us with either guns or mounted troops, and it was necessary to look elsewhere for this vital assistance.

Our organisation provided for the placing in the field of $100,000 \mathrm{men}$, somewhat lacking in cavalry and field artillery; the Government rightly decided that we wanted double the number with a superior proportion of mounted men and at least an adequate number of guns, and proceeded to look for them.

The Colonies loyally coming to our assistance, supplied us with invaluable contingents of both the lacking arms, no longer accepted merely to knit more closely the bonds of Empire, but with heartfelt gratitude, because they. were urgently required. These contingents were most rapidly and efficiently organised and despatched, but not so rapidly;

vol. XLv. 
as they; might have been, had they been considered in time of peace as an integral part of our field army.

The people at home were no whit behindhand. The War Office asked for and readily obtained a Division of 7,000 Mounted Infantry Volunteers, known as the "Imperial Yeomanry," and organised in 20 battalions of 4 companies each, based originally on our Yeomanry Cavalry units. These troops, added to the Colonial motinted contingents, supplied the deficiency in mounted troops, and by their action served almost to turn the tide of war in our favour; but they took many weeks to raise, organise, and train at a critical period when every day was of importance. Rapidly and valiantly was the work carried through, but there was the same flaw as in the Colonial contingents. Organisation must be worked out in peace, not under the stress of war necessities. Many unnecessary hardships were inflicted, and all sorts of minor difficulties, as in the arrangement of pay and equipment, had to be overcome.

Then the Volunteers at home nobly offered to do their share. The City of London, true to its Imperial instincts, not only supplied a splendid battalion of infantry but also helped out our other deficiencies by a battery of field artillery and two strong companies of mounted infantry. The part taken by the Volunteer corps in the rest of Great Britain requires a little explanation to show how useful it was. The mounted infantry in South Africa was also being rapidly increased, each Regular battalion supplying one company (this statement must not be taken too literally, but this was the theory of the organisation), and the corresponding Territorial Volunteer Infantry Brigade at home was asked to organise a company to replace the missing one in the battalion; the depôts at home not having enough trained Regular soldiers of full age to keep the units at full strength. This was readily carried out, but there was the same flaw-nothing had been prepared in time of peace for such a contingency.

Aithough these methods might supply, with some degree of efficiency, the lack of infantry and mounted troops, yet they only contributed in a very slight measure to the call for more artillery. This could only be met effectively by obtaining highly-trained men. Of the three arms, the gunner requires the most training to be only moderately efticient, and so, even had it been possible to rapidly equip the batteries-no mean difficulty to get over-the trained men could not be at once supplied. The need was met by sending away at once practically all the artillery at home;but even this did not suffice to provide guns in anything like a proper proportion for such a force as was now accumulating in South Africa. About 100 batteries would be required, and we could only supply 60 , leaving only two R.H.A. and nire field batteries for home defence, plus a few batteries of Volunteer artillery armed with obsolete guns and quite unfitted to take the field against modern armies. The formation of seven new batteries of horse and fifty-four batteries of field artillery was immediately commenced, but these could scarcely be described as efficient even by the end of the war, for in December, 1900, they were still short in officers, guns, horses, and trained men. It was the best that mortals 
could do then, but how much better if the difficulty had been foreseen and provided for in time of peace!

There was another outcry about the artillery. It was said that the Boer guns were better than ours; but, speaking generally, this was a popular misinterpretation of the facts. Our field and horse artillery guns were admirable weapons for their purpose, but not calculated to compete in range and destructive power with the modern guns of position which the Boers were able to bring up. No European Power mobilises its "field army complete with guns of position, and it is not exactly fair to blame our organisation for not having ready the exact weapons to meet this unlooked-for contingency. The Navy in some sort supplied the deficiency with weapons superior in class and manned by highly-trained seamengunners and Marine artillerymen, but with fittings and equipment hastily improvised for the occasion. A siege train, as already mentioned, was also early despatched armed with weapons quite equal to any brought up by the Boers; but the Garrison Artillery of the siege unit had to be trained in the working of their pieccs after the outbreak of war, and in the Q.F. gun drill were trained at the Naval Gunnery School by seamen. How much better if our siege units had worked the most modern guns of position in time of peace!

In short, the same criticism must be used regarding the artillery reinforcement as for the other arms. It was "rapidly carried out, but not so rapidly and efficiently as if all had bekn prepared in time of peace for such a contingency. It never reached the maximum of efficiency required, and all sorts of minor difficulties in the arrangement of supply, training, and equipment had to be overcome.

\section{Third Phase.}

From the Arrizal of Lord Roberts to the Annevation of the Republics.The repulse at Colenso was followed by a reinforcement of most of the 5th Division and additional cavalry, artillery, and details to General Buller's Natal Army. With this added strength, commencing 9th January, he made the attempt to turn the Boer position from)the westward, which lasted till after the abandonment of Spion Kop on, 24th January, and the discovery on 7th February that the Vaal Krantz position was not the key to Ladysmith.

NIeanwhile General French, who, during December, had forced the Boers back on Colesberg, and nearly captured that place, had also been checked during January by the large reinforcements which the enemy had brought up. Indeed, after Lord Roberts' arrival on 10th January, everything was very quiet all along the front in Cape Colony, probably as regards our side by the orders of the new Commander-in-Chief, and the Boers showing their usual reluctance to attack our troops in position. It was the hush before the storm! All was quietly preparing for a great blow to be struck later on. 
By 6th February about 30,000 additional men had arrived in South Africa, and Lord Roberts was able by the 10th of the month to coneentrate secretly no less than four Infantry and one Cavalry Divisions and corps troops between the Orange and the Modder Rivers. The total strength was about 26,000 infantry, 4,000 cavalry, and, including the siege train and Naval Brigade, 120 guns. By the night of 15th February the Cavalry Division had completed thejr famous flank. march and entered Kimberley, supported in echelon by the 6 th, 7 th, and 9th Divisions, and Cronje commenced his retreat. Kimberley had then been besieged for 124 days, its losses amounted to 38 killed, 133 wounded, and 4 missing. As is usual in long sieges, there had been more deaths from disease, amounting actually to 1,694, only 161 European adults, but large numbers of natives and children. (The death rate among the children in December was 844 per thousand.)

On the 16th February the force turned, eastward in pursuit of Cronje, headed by the 6th Division, while the Cavalry Division with its exhausted horses made a successful effort to head him off. These few days were a period of great privation for horses and men, for in addition to the fact that we had quitted the railway, the Boers had captured a very large convoy at Waterval Drift on the 15th, taking 176 wagons out of 200.

It speaks worlds for our A.S.C. arrangements that this was practically the only instance of importance during the war when our forces in the field were placed on a greatly reduced ration, and this time it was not their fault.

On the 18th, Cronje entrenched at Paardeberg, and the surrounding began. On the afternoon of the 19th, the 7th Division marched in and his encircling was complete; and on the 27 th, Majuba Day, he surrendered. The total number of unwounded prisoners was 3,997 (460 taken during the fighting), 170 wounded, and 6 guns. The prisoners were despatched to. St. Helena. Our casualties only amounted to 1,250, but the loss in horses from overwork was very heavy, and its results were long felt: The bombardment of the camp had been conducted by four 6 -inch B.L. howitzers of the siege train and three machine cannon; three 4.7inch Q.F. and two 12-potnder naval guns; one battery of 5-inch B.L. howitzers; and six batteries R.F.A. ; with seven batteries R.H.x. more or less available for contravallation, but their horses were fair' worn out by the forced march ; thus reaching the, for us, respectable total of nearly 100 guns, and these more or less adapted for the work in hand.

On this same MIajuba Day a fierce battle was raging in Natal. General Buller had now turned the other or left flank of the Colenso position, and had nearly completed the hard fighting which resulted in the relief of Ladysmith on the next day, the 28th February. The Boers had been weakened by some 5,000 men sent to oppose Lord Roberts, thus leaving perhaps only about the same number to oppose Buller, with possibly another 5,000 round Ladysmith. Sir George White had not more than 6,000 capable of manning his lines, and Buller about 24,000 fit for duty. His guns included four 5-inch B.L. siege guns, two $4 \cdot 7$-inch Q.F. and six 12-pounder naval guns, one battery R.H.A., eight 
batteries R.F.A. (one being howitzer), and one mountain battery, or a total of agbout 70 guns; so at last we were learning something 'of the right organisation. Moreover, the large accession of mounted infantry was now beginning to be available, and from this point onwards there is little variety in the history. The right kind of force had been organised at last, and Lord Roberts made a slow, regular, but contested advance via Bloemfontein, 13th March, to Pretoria, 5th.June (and over Laing's Nck by Buller, 10th June), onwards to Koomati Poort, 24th September.

Our progress was slow because, in the first place, though we hád now nominally a sufficiency of mounted troops to turn the enemy's positions without coinmitting ourselves to the disasters of the frontal attack, yet we could not kcep the horses alive and fit for work in such a country. The privations of the flank mârch to Bloemfontein had cost us dearly in this respect, and the deficiency could only very slowly be made good for the reasons given in the next paragraph.

Secondly, the difficulties of supply hampered us greatly, not as a rule from lack of proper organisation, but as practically inseparable from the country. All our stores could only be conveyed over thousands of miles of inferior railroads, liable to destruction in much of their length. Suchaline was always most difficult to work and protect, and our regimental officers who found themselves in command of posts do not always seem to have acted in the wisest manner or even taken the precautions generally laid down for the fortification of the posts or the safe-guarding of their charge. Over-confidence in immunity from attack seems to have been far too general at first, and led to many minor disasters. Lack of specially trained staff officers for this work accounts for much, but certainly among the lessons of the war must steal in the fact that our regimental officers, as a whole, have not shown themselves experts in the art of war. This matter will be further dealt with in proposals for the re-organisation to follow the war.

Directly our forces left the railway as their line of supply, the difficulty of transport was vastly increased, as instanced in General Buller's movement towards Acton Holmes to turn the right of the Colenso position, or in Lord Roberts' march to Bloemfontein. It was not that the difficulty was a new one or unforeseen, but one simply due to the country and inseparable from South African campaigns, and it is probable that no other European Power would have conouered it more easily. A mountainous and generally arid country with no roads to speak of, where horses cannot live, and singularly subject to heavy thunder showers and continuous rains at certain seasons, which soon malie the tracks thick in mud or fill cvery ravinc or spruit with roaring torrents, it seems to present every difficulty to transport that man can think of. The trek ox-wagon, the usual transport of the country, is cumbrous in the extreme for the transport of a mobile force; about 2,000 of them being required for an army corps occupying an enormous length of road, and in addition they are so slow that, if the teams are to carry their own forage, their power of hauling about $600 \mathrm{lbs}$. is limited to about 50 miles. IVe did all we could to supplement this method by early provision of 
Scotch carts and traction-engines, and we seem to have been buying up all the mules in the world during the past year, and yet never seem to have had enough. To the end of the war we could not move as rapidly as our opponents, and the only columns which were really mobile had to take all their stores on pack-horses or in light carts.

It is so simple to say, "Cut down the transport," but the very critics who suggest this would howl if we ran short of ammunition in a battle, or if we had not entrenching or other tools avallable for each and every emergency; still, it cannot be denied that the great strategists of history have made war with very much less transport and with many less comforts for the men than has marked the present campaign, or at any rate its commencement.

Napoleon's strategy, like that of Stonewall Jackson, or that of Lord Roberts in the movement on Paardeberg and Blocmfontein, depended for its success very much on the privations which the men had to suffer n order to move and strike quickly. Buller's flank march towards Acton Holmes, where the soldiers always drew a full ration, ceased to be a surprise on account of the slow movements of the columns, which were always being delayed for the transport to come up. An army must be well supplied to kcep fit, and loses its mobility if it is not; yet it also loses this essential mobility if it is delayed by its train; and so tents and full rations are rarely compatible with the most effective strategy. - Hence the difficulty is, to decide what is absolutely necessary as compared with what may with hardship be dispensed with, and then to pack those necessaries and move them with the least length of train, and as expeditiously as possible, and, moreover, so that they may be rapidly got at and distributed. It is in this kind of arrangement so necessary to successful work that Lord Kitchener is reputed to have shown his greatest talent, and so, after his arrival, to have changed the aspect of affairs. A training in Aldershot manœuvres, where officers take with them the comforts of a mess and the luxuries of a picnic, and where the men sleep always in tents after having performed a moderate march and having received a full and carefully cooked ralion is not a useful preparation for war. Yet the blame for the whole matter seems to rest on the British public rather than on the War Office or the General. Should our men at Aldershot suffer from a long march or an exceptionally hot day, or in a campaign from lack occasionally of a full meal, the Press begins to howl, and the public back up the Press by writing letters and demanding an inquiry, which is readily granted by a Government which depends on the people for its power. It is rarely the-soldier who makes the complaint ; he understands that these privations are necessary for successful war, and is well content to suffer if he can only win. The fault then must lie with the people, or with those whose duty it is to educate the people in these matters. There is another point: in a voluntary Army the soldier's life must be imade comfortable and attractive, or we cannot get recruits. Every time the Press shricks about sunstroke, bad rations, or neglect of the wounded, it means a.reduction in the intake of recruits. Conscription, or a more thoughtful Press, are the only cures for this: 
India is often described as the best field of training of the British Army, and in many things this is so, but not in this question of transport, for the tent there is a necessity as a protection from a pitiless sun; and labour (native labour) is so readily obtainable that a host of campfollowers are deemed also a necessary. There are, of course, other reasons for the exceptionally large number of camp-followers besides the cheapness of labour, but they are readily understood by all who know anything of India, without being enumerated here.

In any case, the transport organisation became much improved in every respect during:the third phase, and the lesson was then and there taken to heart and profited by. Eventually, by October, 1900, Lord Roberts had formally annexed the two Republics, and reduced the fighting to a guerilla resistance so hard to stamp out in such a country and against such a foe.

In that same month (October) Lord Wolseley said that we had been able to send from these shores and its dependencies an army of 234,000 men, accompanied by 170,000 horses; and had sent them 7,000 miles.

A Parliamentary paper issued in December, 1900-at that time many men were under orders for the front-showed that, including the 9,622 troops in garrison in South Africa on 1st August, 1899, we had sent out 267,211. From this total we had to deduct :-

\begin{tabular}{|c|c|c|c|}
\hline Killed in action - & - & $\begin{array}{c}\text { Officers. } \\
-\quad 311\end{array}$ & $\begin{array}{l}\text { Men. } \\
3,018\end{array}$ \\
\hline Died of wounds - & - & 93 & 952 \\
\hline Died of disease, accident, & etc. & 171 & 6,834 \\
\hline Total deaths in South & Africa - & 575 & 10,804 \\
\hline Still missing and prisoners & - & 14 & 1,236 \\
\hline Sent home as invalids - & - & - $\quad 1,575$ & 35,548 \\
\hline $\begin{array}{l}\text { Total reduction South } \\
\text { African Field Force }\end{array}$ & & - & 47,588 \\
\hline
\end{tabular}

1,172 Colonials and 8,795 Volunteers and Regular troops not invalided had also left, reducing-the force out there to 207,492. The total estimated for out there was slightly different, round numbers being used, and probably many of those shown as missing had rejoined without being reported. The total was made up as follows:-

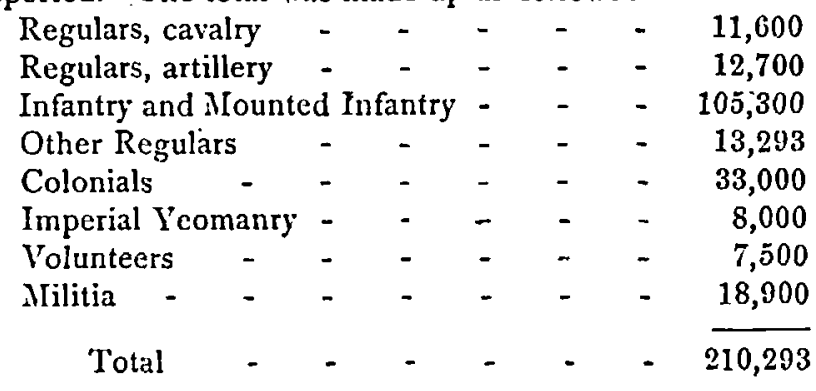


At the same time the total reduction of our military forces during the war was :-

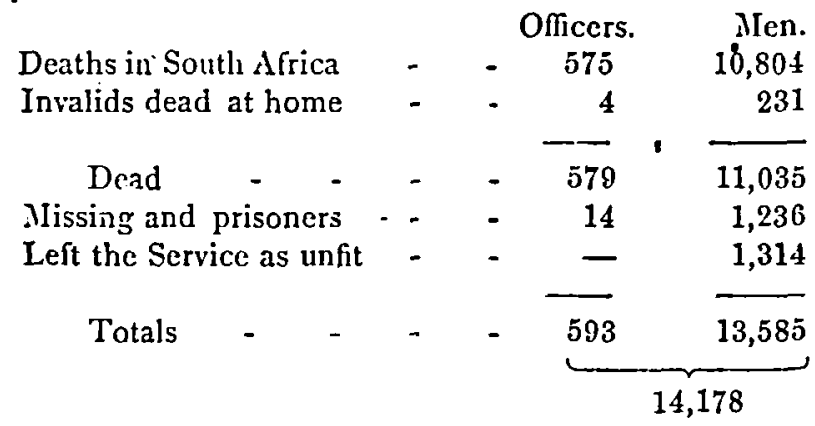

This gives as actually dead or unfitted for the Service after a year of war about 54 per 1,000, or, taking the dead alone, about 47 per 1,000. Not a really heavy bill as compared with previous wars; and the ordinary peace wastage of a battalion from desertion, death, and discharged invalided or worthless is not so very much smaller!

From the total of 207,492 we have to deduct 12,000 men in hospital in South Africa, so it is practically certain that during the whole war we never approached a fighting total of 200,000 , and we thus obtain the following interesting facts :-

To keep up a force of nearly 200,000 men during thirteen months of war in which the casualties were below the average, we had to despatch 207,211 men, and of these our Regular Army could supply little more than half; of the remainder approximately 40,000 coming from the Colonies, 20,000 from the Militia, 10,000 from the Volunteers, and 8,000 Imperial Yeomanry, all this exclusive of South African Town. Guards, etc.

Nor was the Regular Army for home defence in any better plight. The actual state of the artillery has already been given in detail, but the other arms were in very much the same condition. After despatching the troops in the beginning of 1900 , besides the three regiments of Household Cavalry, there were only five other's in the British Isles'; in addition to the three battalions of Foor Guards at home, there were only six other Regular battalions ; of 123 Militia battalions, all embodied, 30 went to South Africa, one to St. Heleria, one to Egypt, three to Malta, and two to the Channel lslands, leaving only 86 at home; the Const Defence Artillery were not so hardly put to it, as they were strengthened by a large body of Artillery Militia, and so were able, to a certain extent, to relieve the strain on the mounted branches of the Royal Regiment; but the Royal Engineers were in exactly the same condition as the other arms, and field companies had to be hastily organised or converted from fortress units. Behind this petty force we had some crowded depôt squadrons and batialions unfit to take the ficld, the bulk of the Volunteers, and the great untrained and unmilitary shop-keeper class of these islands who had only so far sent an occasional representative to share in the fighting, and last and greatest, the Royal Navy, on

' T'wo of which were under orders for South Africa in December, 1900. 
whose offensive power, under God, the safety of the British Isles depended.

The British and Imperial instincts rang true throughout the Queen's dominions, but nowhere more than in the heart of the Empire, and directly Parliament assembled ${ }^{1}$ plans were laid before it which should provide an Army for home defence. From the composition of this Army many lessons for a future organisation may be lcarnt.

In addition to th, extra batteries and A.S.C., to the establishment of the Regular Army were added thirteen infantry battalions in augmentation of existing territorial regiments, and a new regiment of Irish Guards was created, only to consist of one battalion for the presec.. As a temporary measure during the war, Royal Reserve Regiments of veteran soldiers were raised by Royal Proclamation, four being of cavalry, one battalion of Foot Guards, and eighteen battalions of infantry. The men attracted to the ranks of these new units by pay of an exceptional kind, were required to be all old soldiers or Marines, and a very fine and reliable body of men they turned out to be, indicating. that we lose the trained Reserve at a too early age.

Do the bare statements given above convey an exaggerated idea of the defenceless state of the country against invasion? The people were always being re-assured by the státement that there had never been more men under arms than we had during the summer of 1900 , but while admitting its truth, the statement requires some analysis. Who were crowding up the barracks? Every regiment of cavalry had left a very large reserve squadron behind to take the recruits and men under 20 years of age who had been replaced in the ranks by Reservists: these men made a respectable show on parade. The new horse and field batteries were gradually taking shape, the personnel consisting of the same kind of men as the squadrons but stiffened by the addition of Royal Reserve artillerymen; but horses and guns came but slowly, the former largely from Argentina and the latter from Germany, and scarcely a battery was really fit to take the field. Nearly half of the Line battalions at home had been left behind as already cxplained, and these men went to form the new battallons or to stiffen the embodied Militia. It was thus quite usual to find crowding up the same barracks the two half-formed new battalions of a Regular regiment, or-and perhaps this was the most common-a weak Militia battalion and the recruits of the Regulars at the front; and certainly in one case, and if not in one barrack, at least in the same town, an old Regular battalion, two newly formed ones, and a Militia battalion of the same territorial regiment, to which were attached recruits of other regiments! A hopeless milange of cadres without a seasonable stiffening of trained soldiers. This was our Army for home defence: quite unifted to take the field; and though doubtless it would have given a good account of itself, it could not be called a Regular Army in the usual sense of the expression, which implies a force carefully trained and organised in time of peace. 
The later battalions of both Militia and Regulars sent to the front were not up to full strength, and every Reservist and man of full age was sent out. This meant taking from the other Militia battalions the Militia Reserve, numbering about 30,000 of the best men, and leaving the residue consequently.inefficient. It must be added to the indictment that at this time India was short by 10,000 of its British garrison-an arrangement always to be deprecated-and that during the trooping season of 1899-1900 none of the Regular drafts were sent to the units out there, so that they were gradually falling below strength; our Colonial garrisons also were not in their usual state of efficiency.

More men were certainly under arms in England last summer than usual, but never for thirty or forty years previously had we had so small a Reserve bchind the first line assembled in camp and barracks. The Army Reserve and Militia called out and even the old soldiers specially enlisted, there was absolutely nothing left but the Volunteers (there is no word to be said against them, and during this time of stress they had done splendidly and fully justified their existence); but there is a certain danger behind this justification. They exist to back up a Regular Army, not to replace it. They have no cavalry, no modern mobile artillery, and in all arms lack that thorough training and discipline which should mark the Regular soldier, and more and more every year their recruits are drawn from the same class as the recruits of the Regular Army, and so can put in no claim for greater confidence in their trustworthiness as coming from a better-to-do or more educated class than the Regular. The great middle class of the nation remains practically untouched by our military organisation, and supplies no proper quota to our ranks either for attack or defence. This is a real national danger, which does not exist in any other country in Ejrope.

The whole populace of Europe has seemed to sympathise with the Boers and to have hated us, yet it is an exaggeration to say that the country was in real danger of invasion. It cannot be too often repeated that so long as the Navy is maintained at its right strength such a danger does not exist; and without a paramount Navy, our Empire must also perish. Then it is a real mistake to spend too much on a force which is only organised to protect us from a danger which should never exist; and the Volunteers have told us in no uncertain voice that the money which was spent this year to give them an extra training was wasted. The Volunteers themselves did not want it, did not appreciate it, and as a rule did not profit by it; and the extra musketry course was nearly everywhere a complete farce. Certain corps may have been improved by the training, but speaking generally the money could have been more'profitably employed in providing a force suited to our Imperial needs.

Where our system broke down badly was in providing an expeditionary force of 200,000 men to deal a hostile blow over seas, and, looking generally at our past history and our probable future need, that is the use

1 The 16th Lancers and two batteries R.F.d. had been sent additional to force Appendix 1 . 
of our land forces. We may at any moment require double this number to bring a war against a formidable Power to any sort of conclusion ; four times the number to be really victorious on land, and ten times the number to cope with the land forces of the Great European Powers.

Regarded in this light, our military organisation is criminally inadequate. To put the whole blame on the War Office is worse than unfairit is ridiculous. The Empire as a whole has been warned repeatedly that such a breakdown might happen, and when it was told definitely that we were only prepared to put two army corps into the field for a foreign campaign, while other nations could put twenty, had fecbly doubted if we could do even that much, but had been on the whole fairly content with that promise. What the War Office had promised the War Office had done, and done it with a celerity that disarms honest criticism. It had mobilised and dispatched a larger force more accurately and more completely than ever before in our history; and, taking distances and other matters into proper consideration, had beaten also the world's record. Yet, passing away from the consideration of the Third Phase alone to "General Lessons of the War," was not the result eminently unsatisfactory? Would it not be worth the country's while to look into the matter? Perhaps the omnipotent elector and taxpayer may have forgotten that in order to break the power of Napoleon, besides having the command of the sea, we had to pay ábout $£ 50,000,000$ in subsidies to other Powers to help them keep their forces in the field, and that because our own Army was too small for its work. In those years the national debt went up from $£ 110,000,000$ to $£^{900,000,000}$, with taxation in proportion. Armaments are far more costly and vastly larger now, so that these figures, enormous though they may seem, are nothing to what we might have to pay in a war with a European Power to procure peace, even though we had the most undisputed command of the sea, because we have no Army capable of dealing a blow on land. At present the Empire has no right to complain of the War Office; the matter is in its own hands! With a voluntary Army and with the money voted, nothing better can 'be donc: The mobilisation of 1899 was simply excellent as a mere work of organisation compared with most examples of history; with the Crimean Expedition; with Egypt, 1882 ; with the invasion of Cuba; and so on. The country had got exactly what it had been satisfied to be promised, and more than it had paid for, for the Estimates do not cover the zeal in peace-time of hundreds of soldiers and civilians who have been doing far more than they have ever hoped to be rewarded for; and, on the outbreak of war, no Estimates cover the glad enthusiasm of the Services and of the Empire as a whole, which either made light of the hardest tasks, or encouraged, aided, or kept off despondency, according to the particular lot of the individual. .

iVe had to take cxtraordinary measures to raise an expeditionary force large enough to conquer two insignificant Republics, and therefore were completely incapable of terminating a favourable naval campaign against a European Power by a coup-de-grace dealt ashore. Still, with practically no trained and organised Army left at home, we were in no real 
danger of invasion. Hence it is suggested that the most suitable form of national expenditure, after assuring naval predominance, is to prepare during peace a powerful Army for service abroad rathet than one for home defence; remembering always that the force for offensive strokes is still available for defence until such time as the war can be carried into the enemy's country. The value of the Volunteers is not disputed, insomuch as they gave invaluable assistance to the expeditionary force, but their training should adapt them a little more for this purpose: we could not send them to China the other day, for instance. They would be of more value, too, if they touched a higher class than that from which the Regular troops are now drawn, and the country seems to require to be warned against trusting to this force as trained at present as though they were anything like equal to a mobile Army of the same numbers. Perhaps, indeed, there might be a little money left over for a mere defensive force, after we had carried out the two main objects; but, at whatever cost, the two main Imperial objects should be carried out. In all this stress of war of 1900 , there is no nation whose average of wealth, of comfort, or of luxury can equal ours; and a little less of each all round would only tend to improve the race by hardening it. Make life too easy, and there follow in a sure succession effeminacy and the incapability for hard and strenuous work. At any rate, a largely increased expenditure on the Army might not be such an unprofitable matter as a mere matter of assurance to gain peace, judging from the quoted expenditure in the Napoleonic wars.

So far the criticism has been confined to the total numbers obtainable, but there is much more to be said about the quality of the personnel and its training. However large a Regular Army we might have had available at home in the autumn of 1899 , there is no evidence that we should have thought it necessary to mobilise.more men than we did until we had been taught in the hard school of experience. There is no branch of military science which teaches that 70,000 trained soldiers should be unable to conquer an equal number of partially trained farmers, etc., such as composed the Boer armies.

In short, it cannot be disguised that the quality of our force was not good enough. The officers were not highly enough trained, and the men, plucky and self-denying as they undoubtedly were, in addition to some lack of training, had neither the physique nor the stamina for the work.

To begin with the officers. At the period of greatest stress there were practically no Regular officers left in England except those holding such appointments as are more indispensable in war than peace. When we call up our Reserves we have no Reserve officers proper who would come in automatically to their units as would be the case on the Continent, and certainly that we should be short of officers to any serious extent is a matter that had not been generally recognised. There always seemed to be so many retired officers about who expressed themselves willing to serve, or who were enrolled in the Reserve of Officers; there were always so many candidates for the compctitive examinations, and so 
many of the unsuccessful ones seemed to write letters to the papers lamenting their loss of a career, that we always thought that to fill up the cadres with officers could not present any serious difficulty: Let us see what happened. By Christmas; 1899 , the units in the field were only kept officered by borrowing from Militia and other units. The hundred and one billets it was necessàry to fill up for Staff and Line of Communications could only be filled by taking Marine officers and those on the Indian establishments. The Military Schools were interfered with. The Staff College was closed altogether. Instructors were taken from Sandhurst, and the senior classes of cadets, both there and at Woolwich, were taken with their course uncompleted. In short, by that time all the ordinary sources for obtaining trained and qualified officers of certain ranks were exhausted, and the worst strain was yet to come. 'The ranks in the Regular service which it is difficult to fill up in war are those of captain and trained subaltern. Many captains are necessary for Staff appointments as well as those indispensable for regimental duties; and those on the list of the Reserve of Officers of a suitable age are not nearly enough to replace those required for the extra posts. Captains in sufficient numbers can, of course, be obtained by the process of promoting the senior subalterns, but these latter are the very officers most expended in war both by bullets and disease, and this means of supplying captains soon comes to an end and leaves the units in a very bad state indeed. To have nothing but inexperienced subalterns fresh from a cadet college is not good for troops going into action for the first time, and the number of non-commissioned officers who can or will take a commission is very limited. For the troops at home these ordinary channels for supplying officers was completely cxhausted, and we were very soon taking officers who had no military education whatever. With the raising of the new units in February, more and more young officers were required. We obtained them in large batches by nomination from the Universities and by direct appointment of various kinds, and cirtainly the officering of the new units was no small part of that general unfitness to take the field to which reference has already been made. A battalion would be commanded by a colonel (possibly from the Reserve) assisted by a Reserve major and possibly one captain from the same source, and then a batch of newly appointed second lieutenants with no military experience whatever. Undoubtedly the most useful age for a regimental officer is between twenty-five and forty, and it was a just distribution of officers between these ages which was lacking. The squadron, battery, and company officers were either too old for their work or too inexperienced. The only cure for a recurrence of this defect, in its present aggravated form, appcars to be the very considerable increase of the reserve list of officers, and to make it include young officers with some training as well as those who have retircd from age or left the Service because they were tired of it. Evidently from the comparative ease with which the Imperial Yeomanry was officered there is plenty of good material in the country for the Reserve, but equally evidently we have not yet discovered the way to induce these gentlemen to prepare themselies for war, for we cannot 
get them to join the Militia or Volunteers in time of peace. For years the great difficulty of obtaining officers for these Services has been one of their defects: and our need is far greater than this, for we also require many more officers for the Regular Army on mobilisation, when the Militia and Volunteers require all their own officers. Our previous mobilisations have always been so partial that our faulty system of borrowing officers from the units not mobilised has always sufficed to bring our expeditionary forces to war strength, and the extra staff officers for line of communication and other duties have alway's been obtained, as in the present case, by special service officers. Now this system, besides being obviously unsuited to a complete mobilisation, may also give rise to a mistaken method of obtaining our generals. The only officers in these days selected for promotion are rightly those with war service, hence to pick a man from his unit for special service is practically to pick him for special promotion, if he only does fairly on his campaign. Now there is certainly an idea in our Service that the simplest way to get selected for this kind of work is to come to the front at home socially or in some kind of sport, so that the good regimental officer who is more devoted to his work than his play does not get quite a fair chance when these special missions are going. It would surely be a more complete system of organisation if staff officers could be openly appointed in time of peace to the units they would join on mobilisation, and if the officers selected for special service could be taken on recommendation from commanding officers of regiments mobilised for that part of the theatre, and if we had a reserve of young officers trained and ready to bring up our units on mobilisation to war strength and to replace those officers who may bc required for staff and special service, and to fill up the first casualties. It would seem desirable that, as on the Continent, these reserve officers should belong to particular units in time of peace, and train or manœuvre with them occasionally. That these officers cannot be raised and trained without some special inducement is another sufficiontly self-evident fact.

But more serious still than the lack of officers is the charge of incapability which has been raised against them. Taking the case of regimental officers first, the attack on them by newspaper correspondents has not been very serious, as a rule limiting itself to the vague statements that they are not worked enough in time of peace, and think more of their social than their military duties. It is easy to make an assertion of this kind, but not easy either to prove or disprove it: the average Briton does not wear his heart on his sleeve, and it may just be possible that the journalist who is not really intimate with the Service does not understand a certain mannerism and façon de parler which are common in the Service.

On the other hand, most soldiers will admit that some considerable ignorance of our trade has been displayed by the commissioned ranks, and that it would be quite possible to do a little more work; but the majority will be inclined to add, "Why should we?" If a man only" earns half of his income by a profession, is it not logical that he should 
only give half of his time to it, unless there is such competition that he must either work or give place to a better man? Of course there is patriotism to be taken into the equation, but such a sentiment alone will scarcely keep a man at work year in year out in the dull routine of a garrison town. These are home-truths, but they and the following are what many soldiers are saying at the present time: "If you can get a better man for the job at the price, do so." "Our patriotism is quite strong enough to make us help you; our keenness will make us do a certain amount of work for the love of the thing; but if we are to give up our whole time, it is not unnatural to expect that we should be paid as in any other profession." "The only other cure is in compulsory service, but that is a question to be dealt with separately. A word of warning to those of the British public who are asking for better officers: Owing to the sudden demand for officers just now, all the examinations have been made simpler (except for sappers they were never really very stiff), and many officers have been given their commissions without any military schooling at all, and thus the only effect of the war so far has been to lower the standard of intellectual attainments rather than raise them, so it will not be surprising if the young officer of the immediate future is somewhat less still of a shining light intellectually than his immediate forbears. Moreover, for the extra units raised, an extra flow of candidates will always be required, and either the attractions of the Service must be permanently raised or the intellectual standard permanently lowered, if we are going to keep to a voluntary Army. An afficer in the Army cannot live on his pay as things are at present, and in a free country it is impossible to keep moneyed officers out of the Service and prevent them from raising the general rate of living of the remainder. An officer of the Royal Marines can very nearly live on the same rate of pay, but this is only made possible by very carefully organised permanent messes at head-quarters, which the Admiralty helps to kecp up, and by the assisted messing afloat. Such an economical system is impossible in the shifting messes of the field army, unless the. War Office will step in and furnish the messes and the quarters as is done in the Navy. It is argued by many that if the Service were made more economical we should get a more hardworking class for the commissioned ranks, sons of officers and clergymen, etc., who are at present debarred by the expense from joining. This remains to be proved; there is no hope of future increase of income as in other professions, and the man who joins poor will remain poor all his life. The places taken in the competitive examinations for the Marines are a trifle higher on the average than those for the Artillery and Line, but then the parents of the Mlarine officer are spared the expenses of Sandhurst or Woolwich, which makes parental influence very urgent.

It would be a step in the right direction if the country would educate all its officers free of cost, as so many sons of officers and gentlemen are kept from entering Sandhurst, Woolwich, or the Militia by the cxpenses of those methods of joining the Service. It is certainly to be hoped that the educational standard will not be permanently lowered. 
It is quite low nough already, lower than that of France or Germany or United States; and if a physical test were in part substituted, it would be a retrogade step. No one has complained of the lack of physique of our officers on campaign, and the strong man does not necessarily make the best leader ; endurance is not to be tested by strength or weight, and is probably more a mental quality than a physical one. Certainly, those who take low places in the competitive examinations do not scem to be any stronger than those at the top, and on the average are far idler and less efficient officers.

With regard to the higher education of staff officers, there has been a great deal of public criticism during the war directed against the Staff College, but very little of this will bear close examination. However, lest we omit a lesson, let us see what it amounts to. The first charge takes as a standard our works on tactics and strategy, mainly written by Staff College men and based on our own or foreign experience, and blames our officers for neglecting some axiom of those books.

The second charge blames the officer for slavish attachment tò those books in a country and against a foe for which they were never intended. They, the charges, simply amount to this: it is wrong to fail, and must be due to either too much teaching or too little, and in either case the educational arrangement must be wrong; but whether our officers are taught too much or too little, the ritics cannot decide. The fact is, that in war. no one can be always right, and it is hopeless to expect that any system of education will make a perfect officer, but it has certainly not' been clearly proved by anyone that we could have done as well or better without a Staff College. Such tactics as we have at present have emanated from the Staff College, and without such an institution our general scrvice knowledge of tactics would be back in the dark ages. Also it has been pointed out that some of our most successful generals have not been Staff College men, while others less successful have had that training. This is scarcely a proof of anything, but in any case the Staff College training of twenty years ago-the period when these generals would have been studying there-is not of much use to the officer of to-day. Unless an officer has kept up with the times, and improved his theoretical work by practical experience, he cannot figure as an expert, and for neglect of this after-work the present Staff College course is scarcely to blame. Might it not be possible to have some kind of revising course occasionally, so that officers could go back to the College for a few weeks to hear the very latest ideas?

A politician had recently to apologise for an election speech in which he playfully suggested that De Wet, when caught, should be made a professor at the Staff-College. There is a great deal in the suggestion read in an altered form, that we should always have some Colonial officers at the Staff College, then, at least whatever portion of the Empire was discussed, we should have at hand a man who really understood the situation. But it is interesting to note at the Staff College, when Indian affairs cropped up, those young officers who had real frontier experience were not more listened to than the man who could 
write or talk vrilliantly on any subject, of course including the frontier question in dispute, and this tends to diminish the one-sided view. People who live on the spot are to be listened to gravely and seriously, and everything is improved by their presence; but the almost inevitable narrow-mindedness or concentration on the subject requires to be a little discounted. A propos of this, there seems to be a source of danger in that we seem to be about to reform our, Army as though all our future wars would take place in South Africa, on the same principle that the Staff College for thirty years has done little else but analyse and thrash out the lessons of the Franco-German war. Let us now take a wider view, and, by including the ends of our Empire in our military conferences, endeavour to keep our views broad and adequate to the needs of the Empire as a whole. Further, let us try to rid the Service of the idea that the theory of war is a thing which must be confined to the blackboard and kept alike out of our peace and war mancuvres. If our theories will not work, it is not that the study of war is wrong, but that the professor has become narrow-minded and must give place to one with broader experience. So far as one can judge, the errors of the war have been mainly due to a neglect of theory rather than to a mere slavish following of a blackboard idea. For example, South Africa to-day is said to be strewn with " implements entrenching," bccause the men were not able to carry them, and said that in such a soil they were as useless as pieces of tin. Yet we repeatedly suffered for not entrenching, though our opponents managed to do it inyariably. Perhaps the tool may not have been the best for the purpose, that is merely a reason for reforming the tool or its method of transport, not for saying that the theory of entrenching is impracticable and must be abandoned.

In any case, theory alone will not make a successful general, but lack of it will certainly lead to failure. The carping against the Staff College is not new, and is part and parcel of that English spirit which condemns everyone who reads as a book-worm, and which understands "theory" as being "that which is not practicable," and so will have none of it. It is probably this very spirit that has led to most of our disasters, or, rather, tactical mistakes in South Africa. On search being made too it will be found that those non-"p.s.c." men who have succeeded, have donc so by following Staff College principles, and frequently aided by the Staff College men on their staff. In any case, do nòt let us make a retrograde step, and abolish the place, but rather endeavour to find out what are its defects, for it has many, and improve them. The place has been so snubbed in the past that neither its teaching staff have always been the best officers or those most suited for the work, nor have the candidates always been quite the best, as the rewards for the work have been so small and it has been always possible to get on as well or better without the certificate, for example, as a frequently selected special service officer. If these special service officers are not to be taken purely from the units mobilised, then they should be taken from p.s.c. men in preference to all others as a continuation of the training, for no p.s.c. certificatc should be granted to an officer who is not apparently fit to be a special vol. XLV. 
service officer. But an officer who has displayed the keenness in his profession necessary to take him through a Staff College course should not be hastily judged. Whatever his defects, if he is keen and hardworking, it is probable that he, if given a chance, will overcome them; and in the staff of an Army there are billets for all men of capability ; but there is no room for the incapable, who should be mercilessly rejected at the Staff College itself.

Turning now to the personncl in the ranks, its greatest defect in the British Service has already been alluded to. In the Regular. Army we practically get nothing but the labouring classes, and do not do more than touch the shilled artisans; while the-shop-keeper and small farmer class really give nQ personal' service at all.

So far, every historian of the South African campaign has had nothing but praise for the men in the ranks, yet because he has fought so splendidly is no real reason for burking this matter. In December, 1900, no less than 6.834 men had died of disease in South Africa, and more than 35,000 men had been sent home as invalids out of the grand total of 267,000. This does not definitely prove, of coursc, that the men were of bad physique, since it is a well-known axiom of war that far more perish from discase than by the bullet; still, that the force should be reduced by nearly 20 per cent. of its rank and file by disease alone in a comparatively healthy country is a matter worthy of consideration, in this twenticth century when medical comforts and science and organisation generally have done so much to alleviate the soldier's lot during a campaign. But a glance at the last report of the Inspector-General of Recruiting gives an aelequate reason:-

1. About 34 per cent. of the 1899 recruits were under standard, and known as specials.

2. Out of every thousand recruits, 649 belong to the lowest classes, 141 were artisans, 103 mechanics, 68 shopmen and clerks, 9 were "professional" men fone always wonders whercin they had done wrong or failed in the battle of life), and 30 were boys under 17 . This cannot be a fair specimen of British manhood.

3. In the same thousand, 71 were well educated, 890 were able to read and write, 13 could only read, and; even in these board school days, 17 were unable to either read or write. Is this the best we can do in a yoluntary Army?

4. Of these, 15 per 1,000 are invalided in their first year of service, and 17 in the second. If our system of training is liealthy (and other statistics show that it is), then we cannot have a healthy class to start with; and jet of the men who presented themselves about 320 per 1,000 were rejected at once, which shows that there is a still lower class physically who would serve. Is it from these that we are to get our extra recruits required for the already authorised increase of the Army? 
5. Again, of the recruits who join under our present voluntary system, $3 j$ per 1,000 purchase their discharge within three months for $£ 10$ (presumably from the better class of recruits, since they have this sum available); and a further 34 per 1,000 are allowed to go on paying $f 18$, making a further reduction of the better classes.

6. After all this it is not surprising to learn that out of an Army of 290,914 we lost in the year by desertion 2,482 ; that there were discharged for misconduct 2,158 more; the total discharged as invalids being 3,377 and by purchase 3,623 , and from other causes not specifically explained an item of 1,756 more; or a wastage of 46 per 1,000 in time of peace, which is practically the same rate as the death losses in the first year of the war.

History shows that the residue are keen about their work and eager for fighting, but it is evident the men are not physically or mentally of such a high class as is required in a small voluntary Army like ours. And quite apart from statistics, those of us who are familiar with the appearance of an ordinary British battalion on parade at home, will readily concede that the men are scarcely a good sample of the Empire's manhood. The argument that they are quite up to the standard of Continental troops is easily combated, for if they were to be opposed to French or German Armies they would be outnumbered by ten to one, and therefore should be ten times as good, and the educated men in the ranks of these Armies are an incalculable source of strength.

Were the general average of our recruits over twenty years of age, we should have a real Reserve of 80,000 men and the units would be able to go to the front in something like their peace composition; and while the mobilisation was going on, there would be time to revise the training of the Reservists. It is also the youth and poor stamp of the recruits which make the disease and desertion wastage so high. Not strong enough for their work, they either fall victims to it or desert to avoid it. Of.course this is only a partial reason, and does not include all the causes which lead to this result. Undoubtedly we are afraid to work our men hard for fear of driving them to desert, or what is worse, of preventing the present scanty numbet of men from enlisting. The recruiting in 1899 was better than in previous years on account of the additional trouble that had been taken by the Government and by private goodwill to provide employment for-Reservists; and at the end of the year by the generous way in which Reservists and their families were being treated on mobilisation. If this was a good year, what must the bad be like? In the coming year, 1901, the war fervour will have passed away, and to make good our cnormous wastage we shall have to compcte with the open labour market on very disadvantageous terms. There seems to be no reasonable alternative to paying a greatly increased wage, and by such a system of re-organisation as will make the Army really popular. We cannot make less work one of the inducements, for the 
truining is incomplete enough already, and reports from South Africa show that in scouting, in marksmanship, and in entrenchment work our men were most defective; but the training might be made more practical and more-interesting. It is suggested, for instance, that the extra money to be given in wages should depend on actual skill in the profession of arms; that in every arm there should be at.least two classes of men in the ranks receiving considerably different rates of pay ; in the infantry the classification to depend on marksmanship, and general stamina in marching, to be tested not only by the ordinary musketry course, but also by firing after a long march; in the cavalry, for scouting and reconnaissance duties; in the artillery, as at present, for gunnery and driving respectively; scouts in the infantry and artillery to be regarded as specialists and paid accordingly, ${ }^{2}$ and marksmen in the cavalry to be similarly treated; lack of efficiency in the annual course to cause reduction to the lower,rate of pay again as an exceptional punishment; the pay of N.C.O.'s to be increased, so that the Army becomes a real trade for good men. There should be more instruction actually imparted by the subaltern and less by the sergeant for the mutual improvement of all ranks, but for this there must.be a redistribution of duties; less leave for the subaltern, and he must not be taken from his men for the red-lapism of boards and courts of enquiry, where three officers are constantly being assembled to do the work of tone.

There can be little doubt that troops moved to the front in the modern fashion by ship and train arrive in a very" "soft" state for commencing the actual work of a campaign, but the private soldier rarely comes from a class which will appreciate the value of being "hard" and of exercising the necessary self-denial to arrive in that condition. $\mathrm{He}$ is generally " soft," except when he is made to march to get "hard." But the personal training of the subaltern should teach the importance and the secret of this, for to give him credit the British subaltern is generally in excellent condition, and, if allowed a freer hand with his men in field exercises, such as scouting and outpost work generally, will be keen enough. Another point-General Buller has said that the Boers could see two miles further than our men; but how rarely. do our men cver see two miles at all, and use their eyes to report what they have seen! The town recruit whose vision-field has been mainly limited by the brick walls on the opposite side of the strcet has very small idea of the appearance of country objects even one short mile away, and much may be taught him by the subaltern, who, feeling himself really the instructor, will takc care that he knows more about it than the mun he has to teach. But for real value in scouting and so forth we must depend on the specialists, who will mainly come from country recruits used to look long distances all their lives. For efficient scouts at present we have to look to those subjects of the Empire born and trained in the Colonies, and we might always have a few of them at home as instructors. This reminds one that

We might try 2ul. a day extra for first-class solliers to beyin with, but!again raire the amount if fouml insufticient.

: til. a diay extra. 
so far the lessons of the war treated of have only had reference to the Home Army and not to the best organisation of the land forces of the Empire as a whole.

The grand lesson of the war has probably been the assistance rendered by the Colonies. So far the reports on the mistakes accompanying such aid have not come in, but there must have been blunders of some kind, for in our experience they seem inseparable from matters military ; so it is very hard to draw any further lesson than that already cnunciated. "These contingents were most rapidly and efficiently" organised and despatched, but not so rapidly as they might have been had they been considered in time of peace as an integral part of our field army."

If the Empire means to properly use its strength on the outbreak of war it must properly organise its resources as a whole, and the mere consideration of the formation of the home Regular Army is a very small part of the organisation of those resources. The difficulty lies in that there is no ground-work on which to build a common organisation throughout the Empire. At home we have a Regular Army of boys being trained to provide drafts to beep certain Regular troops, forming the large garrisons of India and the smaller garrisons of certain coaling-stations and Crown Colonies, up to strength; behind these schooling cadres to fill them up to a fighting strength, we have the Reserves; behind them again, a voluntary Militia, more or less neglected and very slightly trained; and in the third line a large force of worse trained and worse disciplined Yeomanry and Volunteers; but covering all a very grand and efficient Navy; the whole costing sixty to seventy millions annually-a great burden, but still less than that endured by the tax-payer on the Continent of Europe. : Up to the present the tax-payer has said little, as in comparison he has had little to complain of, but he has a legitimate grievance if he can prove that he is paying this huge tax to protect the trade of the Colonies. Or the other hand, the Colonies cannot be taxed to provide armaments over which they have no control. So far as our experience of this war shows, directly we have a real need of their assistance it is at once given and with the best will in the world, but no amount of goodwill can make up for neglect of peace organisation, and much of the splendid material is not used to the best advantage. The troops of each Colony are organísed, raised, and trained on slightly different principles, not only from the Imperial troops, but also from one. another. One Colony may be a shade more enthusiastic in its loyalty, and offer a larger or better equipped contingent than another; one Colony may have felt itself more exposed to attack than another and so have had its land forces in a better state of organisation than another, and so on. There is not anything in any Colony which exactly corresponds to our division of our land forces. Militia service in one Colony means one thing, and in. another Colony another; and the different kinds of Volunteers differ more widely still; and taxation for military purposes varies again-some subscribe to the Imperial Navy and some do not. There is no common foundation at 
present on which to organisc. We are all children of a common Empire, but one renders service to the mother in one fashion and one in another. The burden, loyalty, and responsibility are common, and should be borne and shared equally. But this cannot be carried out without some measure of federation; a scheme in which all have an equal roice, and wherein, with the general common-sense and business habits of the British race, none but the experts are expected to speak at all. The late Imperial Federation League has long ago transformed itself into a society which strives only for this end, Federation for attack and defence. Its evolution having taken place at a time when our naval supremacy seemed to be threatened, very naturally its views deal mainly with a common Navy, but after this South African experience it is probable that they will include a federated army.

Then with all gratitude for the loyalty of the Colonies and with every welcome to their ready and invaluable assistance, could not their military resources be organised so as to be of more use to the Empire as a whole, and could not the blood-tax be shared pro ralâ to the interests involved? For this purpose, the Navy, the Field Army, and the Marines might be equally recruited and supported by all, while the Territorial Militia in reserve to the Field Army might be made a similar force in most respects throughout the Empire.

The Volunteers to be given clearly to understand that they only come in fourth line to the Nav, Army, and Territorial Militia, and only after these have been placed on a satisfactory position should they" receive any of the tax-payers' money, because they only half fill an Imperial need; or they might prefer to wholly fill it by placing themselves under a strict discipline and making themselves always available for service abroad; but this seems impossible for the men who compose the force as now constituted in England. With these ideas the building up of the scheme which will fill most of the remainder of the essay will be concerned. Before proceeding to this stage, it will be as well to sum up what may be considered the lessons of the war.

\section{Sumanir of Points Referred to ix Preceding Pages.}

1. Required improvement in the system by which the outposts of the Empire can be rapidly reinforced.

2. Increase of Land Transport Department in men, stores, and horses required.

3. References and suggestions regarding the sea and land transport gènerally:

4. Lack of suitable horses was not confined to :'.e transport service but also extended to all the mounted branches.

5. The number of mounted troops would appear to be sadly deficient.

6. A higher proportion of both mobile and position artillery required. 
7. Organisation of the Reserves capable of improvement.

8. Militia requires and deserves more attention.

9. Our Regular Army is not equal in numbers and quality to the work which it is likely to be cailed on to do in a big war.

10. No plans for utilisation of Ycomanry, Colonial Forces, and Volunteers for service abroad appear to have been prepared.

11. Greater decentralisation in our plans of mobilisation and organisation is seriously required.

12. Peoples of the Continent have shown a marked distrust of our national greatness, and our own population do not suficiently realise the numerical inferiority of our forces. The . Fleet saved us from actual dread of invasion.

13. War training of officers and men requires improvement.

14. Some measure of Imperial Federation highly desirable to properily and equitably distribute taxation and develop the power of the Empire.

\section{Suggestions Focxden on tire Lessons.}

The war in South $A$ frica is not yet, in December, 1000 , fully finished; more reinforcements are still negled; there is a large expeditionary force in China, for which this country. must pay ; the Navy League are clamouring for an increased Navy, and, if they can truly show that our naval supremacy is in any danger, they must have it; the income-tax is at a. shilling in the pound, with indirect taxation in proportion, and the Chancellor of the F.xchequer has told us that we cannot hope for any diminution of taxation from any increased national prosperity; yet short of compulsory scrvice there is no improvement to be made in our land forces without an increased Army estimate. We are face to face with the alternatives: increase d money taxation, or the blood-tax which is borne by the other nations of Europe. Or we can let things drift on in the happy-go-lucky way they have done in the past, and trust that British pluck will as heretofore extricate British stupidity from the diffculties which it has imposed on Empire! Or cannot we join the Emperor of Russia and the peace societies and go in for general disarmament and the arrival of the millenitim?

The nation has wisely rejected these latter procedures, and has been advised that a voluntary system of enlistment is best, and has approved of that advice. Indeed, no practical measure of conscription has been placed in front of it. Experience has shown that the only really equitable method of compulsory service is one under which every able-bodied man of the nation has to serve; and this is beyond our requirements. Such a measure would give us in the United Kingdom alone an Army as large as that of France, which has four land frontiers to guard; and besides giving us too many men and imposing an unnecessary weight on the tax-payer, it does not equitably provide for garrisons over seas or utilise our Colonial forces. Could any means be devised which would fairly limit the numbers? 
If we raise the physical standard with this object in vicw, we penalise the possession of bodily strength, which is scarcely a way to encourage national development; the blood-tax will be paid by the big men alone, and an adequate compensation for this is not readily obtainable. Suppose we go back to the method of the lot alone, then the moment's luck in the drawing of the number will influence the whole of a man's life, which is to give chance too large a voice in the national welfare. Supposing after the lot-drawing we allow substitution; then we introduce the many evils which have always followed this system; if services are to be paid for, then the nation is a fairer pay-master than the individual.

In any case the man's whole lifetime must be affected by his service, for, in the first place, the actual service must come when a man would be learning his trade or profession, and so would handicap him unduly all through life; again, our experience of this year has shown that it is bad national economy to lose the services of our trained men too early; as a Royal Reserve-man, the soldier is of value to the Empire as long as his vigour is unimpaired, and "once a soldier always a soldier" is a truth which must no more be lost sight of by us than it is by the Germans, or other Continertal nations. The limited plan of having conscription only for Home service sees us no further on our way. It does not in peace give us our necessary over-sea garrisons, and in war will do no more for us than the Volunteers whose services for Home Defence it has been said we never ought to require, if the Empire is to exist, as it does at present, wholly by its sea-power.

No, the nation's decision seems to be the wisest and best, if it will follow its decision to its logical conclusion, and make up its mind to pay for the luxury of the exemption: 'Taxation for military purposes can be arranged so as to fall equally on all classes, so that the individual can choose whether he will pay or fight; but those who pay the blood-tax must be fully compensated for their extra liability. No amount of pay per diem can really compensate for loss of life, or limb, or health, or for the hardships of war, but for all these the soldier asks no special compensation. $\mathrm{He}$ is carried through this part of his work by patriotism; by excitement, pride in his trade, kudos or glory, or Imperialissm, or whatever you nuay choose to call it, and more especially by what will be said of his actions at home (and this is the real advantage of a territorial system, wherein the soldier knows that all his actions, good or bad, will be reported to his own kindred and his own people); it is not for this, that he requires compensation in money-these are incalculable-but it is for the daily toil in time of peace which prepares him for these supremer moments. The excellent fighting man who enlists for the love of the fight itself is the last man to patiently labóur to make himself fit for the fight. His is a nature craving excitement, and there is none of this in the unremitting labour which alone can make a modern Army fit for the field, and he seeks for that excitement in sports or worse amusements still. He argues that if he is unprepared for the fight, it is his own skin he risks, and he is willing to accept the gamble; but this will not do for the Empire, which wants a highly trained Army fit to do anything and go anywhere. It is to 
be remembered that all these arguments apply to the officer equally with the men. The officer who joins the Army with an income of $£ 300$ a year or above finds his pay a quite inconsiderable part of his income. $\mathrm{He}$ is willing enough to serve and kecp up a regimental mess on those means so long as the work is not too hard, and he can get plenty of leave to indulge his sporting instincts, which after all are part and parcel of his love for the fight. Curtail this liberty and he says at once, "Oh! if I have to work' I will work at something which will bring me an adequate return for my labour. I can always get up a fight if I want one, and without this grind!"

This state of affairs will not do. We do not want a very large Army, but we do want a very good one. How is it to be obtained? To work from the greater to the less, what probable total number do we require ?

In addition to our existing garrisons abroad, which numbered 118,000 men before the war, and which now might be taken as 150,000 as being a more likely total for future Imperial needs, we require in this country four distinct things at least :-

1. We should be able to despatch at once, without calling out the Reserves, and without interfering with our general mobilisation scheme, a division complete in all arms of 10,000 men. These should be always ready to start.

2. On mobilisation; we should be able to despatch, within a month from the receipt of the order, a further 70,000 men, and that without taking any Reservist who had been more than two years from the ranks.

3. In the next three months we should be able to add to this strength a trained and reliable force of 70,000 more, but these may contain a proportion of Militia, Yeomanry, and Volunteers. Thus, with the aid of 50,000 Colonial troops, to be equally ready, we ought, within three months, to be able to put 200,000 really good troops in the field over seas, without weakening garrisons abroad.

4. Behind all this we should have suitable garrisons for our fortresses, a field army for home defence, and means of keeping the forces in the field at war strength; and on an emergency, our own territories being absolutely secure from attack, to be able to again double the field army to make it a recognisable quantity on the Continent of Europe.

The following would be the composition of the field force in units :-

The first force would be an infantry division, but stronger than at present in guns and mounted troops.

The second would be six infantry and one cavalry divisions with details and line of communication troops.

The third would be a similar force, but with similar divisions to the first added respectively from Canada, Anstralia, and South Africa, with smaller contingents from other Colonies. 
Thus the Empire should be able to provide within three months thirteen infantry and two cavalry divisions" from home, and details, etc., and four infaniry and one cavalry divisions from the Colonies; and behind these an adequate force for home defence capable of even further depletion for service abroad.

No scheme to provide these numbers is really practicable unless it is capable of being evolved from our existing forces. Any utterly revolutionary measure which would quite upset all existing schemes is impossible of acceptance bj the Fnglish people; evolution is the only possible method of progress.

It has been already explained that to mobilise more rapidly and effectively we require greater decentralisation, that our units to be most efficient must be territorial, and that the higher staffs must work with the units in time of peace.

The following scheme renders this possible without changing the designation or localisation of any infantry unit, or upsetting our general military system.

We require six infantry and one cavalry divisions and cletails to be despatched within a month, of mobilisatisn; this geriod might be lessened if the ships could be found ; let this be our first care, and on this necessity build up the scheme, bearing in mind the other requirements.

It is suggested that the United Kingdom be divided into seven territorial divisional commands which, as regards reciuiting, interior economy, and mobilisation, should be completely decentralised. Although conforming as far as possible to existing districts, yet they must purely appertain to the field and territorial troops, and so be absolutely independent of fortress and coast defence commands. For rapid embarkation they will each be connected with independent ports, round which all their plans for service abroad will centre. These seven places of embarkation will be the Clyde, Mersey, Humber, Thames, Solent, Severn, and Cork Harbour; but Southampton to have the extra strain of the embarkation of the first or independent division, part of the cavalry divisions, and miscellaneous troops of the expedition. The divisions being known as (keeping as much as possible to existing. names), the Scottish, North-Western, North-Eastern, Home, Salisbury, Western and Irish, Aldershot keeping the ever-ready infantry division and one cavalry division, and the details; Salisbury to have a cavalry brigade and the Curragh another, and these two places to help with line of communication and other details. To each divisional district would be allotted territorial regiments of cavalry, of field artillery, of field engineers, A.S.C., and R.A.M.C.; so that for expeditionary purposes each division would be self-complete, except for what are now known as "corps" details mobilised at the places already given. The boundaries of districts would have to be so extended inwards as to give fairly equal recruiting fields, and in each division would be two territorial brigades involving merely the existing territorial regiments. These brigades might be for instance :- 


\begin{tabular}{|c|c|c|c|}
\hline Scottish Division & & & $\begin{array}{l}\text { Highland Brigade. } \\
\text { Border Brigade. }\end{array}$ \\
\hline North-lWestern Di & rision - & & $\begin{array}{l}\text { North-Lancashire Brigade. } \\
\text { South-Lancashire Brigade. }\end{array}$ \\
\hline North-Eastern Div & ision & - & $\begin{array}{l}\text { Yorkshire Brigade. } \\
\text { Northern-Midland Brigade. }\end{array}$ \\
\hline Home Division & - & - & $\begin{array}{l}\text { Eastern Brigade. } \\
\text { South-Eastern Brigade. }\end{array}$ \\
\hline Salisbury Division & - & & $\begin{array}{l}\text { Southern-Midland Brigade. } \\
\text { Southern Brigade. }\end{array}$ \\
\hline Western Division & - & & $\begin{array}{l}\text { Welsh Brigade. } \\
\text { South-Western Brigade. }\end{array}$ \\
\hline Irish Division & - & & $\begin{array}{l}\text { Dublin Brigade. } \\
\text { Cork Brigade. }\end{array}$ \\
\hline
\end{tabular}

Leaving as unterritorial, and therefore available for general disposition, the Guards' Brigade, and the Rifles to be combined with Guards to form an 8th Division, with Guards, cavalry, and artillery.

It still remains to show how this evolution would fulfil Imperial necds, and to do this one must go into details. Taking the infantry' first: The infantry brigades will, with the now existing territorial regiments, cover the districts recruiting atout twelve Regular battalions each-of these at least four battalions should always be quartered in the brigade district to work together under the brigadier who will command them in war; this will allow eight battalions for other disposition; of these probably at least four will be serving abroad, leaving four battalions of each brigade to be serving in fortresses at home or in Ireland. The foreign service roster could bc worked out either by brigades or divisions; the first battalions for foreign service will always be at war strength with men of full age, and eight of these will be at Aldershot in the ever-ready division; when a battalion goes abroal the next battalion on the roster will be made up to war-strength and so on, the remaining battalions of the brigade supplying drafts to foreign units. On a relieved battalion returning home it will first serve in a fortress, etc., till it becomes 4 th or ath for service, when it will move to the territorial district. Fach brigade will require in its own district a separate camp or training ground, and these the country must provide. In the ordinary year's work as soon as a brigade has completed its training it will be joined in its camp by a territorial Militia brigade, h-inging it up to the strength of an infantry division, different Militia battalions taking part in these exercises in different years. Nounted troops of the divisional regiments will be dctailed to share in these exercises as occasion may require. Similarly, for an August fortnight, one of the Volunteer brigades of the district will replace the Militia, Yeomanry Cavalry and Volunteer Artillery and Engineers replaciug the divisional detachments. Then in September will follow the regular divisional exercises, two or more divisions being mobilised against each other. The apparent objection to this scheme, that battalions returning alway's to the same district will get to know the whole ground, will be removed by these manœurres which will take place on different frontiers of the districts in different years. 
Units will be maile up to war stren 3 th by calling to the ranks Rescrvists who have been more than two years' from the colours, Reserve officers also serving with the units, and there should be a real test of the district transport and equipment. Thus during the training season the young troops in battalion and brigade training will work over ground familiar to the officers, but for the final exercise the ground will be new to all.

As soon as the mancuvres are over the battalions lying in their own districts will be able to recruit for themselves, and a great effort will be made during the autumn to sweep in as many recruits as possible, so that all can carry out the recruits' training together. The route marches will be made to different recruiting fields of the districts with this object. Meanwhile also the drafts for abroad will be under preparation, and if the men taken as recruits the year before were of full age, enough should be available for two years' service with the complete training of one year as recruits and another as trained soldiers in the ranks.

The other arms will work on similar lines.

The territorial cavalry will contain about four of our existing regiments-one or two will be abroad, one will be serving with the territorial division, and the other with the cavalry brigades at Aldershot, Salisbury, and the Curragh.

The territorial regiment of field artillery will similarly contain about three R.H.A. and twenty R.F.A. batteries and depôt batteries; of the horse artillery, one battery will be in the district, one abroad, and one with the big cavalry units; of the field there will be about ten abroad, six with the division, and four for general disposal. It is probable that the introduction of Q.F. guns may make it desirable to reduce the number of guns per battery, and consequently increase the number of batteries in a brigade division, but this change - would not alter the general arrangement.

Engineers, A.S.C., and R.A.M.C. would be worked on the same general lines. Whether officers would be promoted on one general list or only in the territorial regiments is a scparate question, and to be dealt with on its merits in each arm of the Service. For the present it would not seem to be practicable to carry out the foreign service reliefs in any bigger units than at present, but that might come for Indian Service, at any rate. The reason why "army corps" have "never been mentioned in the scheme has been shown to be founded on our South African and other war experiences; at any rate, with our present strength they could never work together in peace, have never worked together in war, and so their formation may well be left till the occasion shows the need. But what we now call " corps troops" would be assembled at Aldershot and Salisbury for exercise together and on mobilisation, and for Ireland at the Curragh. Each division would be so far stronger than our present ones in that they would each have a complete regiment of cavalry and a corps of mounted infantry, and one battery R.H.A., and two brigade divisions of field artillery.

So much for peace routine. What would happen in war? 
To cover a landing, reinforce an outpost, or to protect an advanced depott, there will be the ever-ready division at Aldershot to leave (if required, alone, for a small war), or while the remainder were mobilising, its departure not affecting the main scheme at all. Units for this would require to be carefully chosen. so that they could put in a complete season at Aldershot before going abroad.

On mobilisation, the territorial divisions fill up to war strength with Reservists under two years away from the colours, and embark automatically and independently as much as possible without troubling Head Quarters; a branch of the Naval Transport Department seeing to the ships at the divisional port of embarkation. As, the units of the first territorial divisions leave, so they will be automatically replaced, unit for unit, by the troops for the Reserve Division, which will be mobilised as follows :-

The Reserve territorial brigades will be formed by battalions from fortresses replaced by Militia, and by Militia baittalions; the cavalry and artillery will form Reserve regiments and batteries for which the horses and guns will have been provided, and the men mainly coming from the Reserve, but with an addition of surplus men from the Regular units; and for the cavalry some Yeomen, and for the artillery some Volunteers.

These units should be ready for embarkation within three months, being again replaced oy fresh units formed from the Royal Reserves, Militia, Yeomanry, and Volunteers, with a percentage of Regular recruits and Reserves.

Let us again see what these numbers mean :-

\begin{tabular}{|c|c|c|c|}
\hline Abroad in peace & - & - & 150,000 \\
\hline Ever-ready division & $\mathrm{a}-$ & - & 10,000 \\
\hline Garrisons of home & fortresses & - & 40,000 \\
\hline First expeditionary & force - & - & 100,000 \\
\hline Reserve expedition & ary force & - & 100,000 \\
\hline Royal Reserve expe & editionary force & - & 100,000 \\
\hline Residue at home & - & - & 200,000 \\
\hline
\end{tabular}

Provided by :-

300,000 Regular trọops.

100,000 Reserves under 12 years' service.

25,000 Royal Reserves over 12 years.

125,000 Reliable MIilitia.

25,000 Yeomanry Cavalry.

25,000 Volunteer Field Artillery fit for service. 200,000 other Volunteers.

Total - 800,000, giving 100,000 spare for contingencies.

It is impossible in a few pages to give all the details of such a scheme as this, and there would always be many discrepancies for which practical working alone could find a solution, but some points not made clear may be further explained. 
70,000 men and six infantry divisions were given for each expedition, and seven infantry divisions and 100,000 men have been estimated for; well, the lesser total is the actual fighting strength, and omits details and line of communication troops.

Nothing has been said of the Guards' Division; there would be $\mathbf{1 0 , 0 0 0}$ extra in hand for contingencies.

The mounted infantry would be divisional units, organised and formed in the divisional areas.

The cavalry and artillery régiments would have to be most carefully organised, to be capable of expansion by their Reservists to the quadruple strength, and the squadrons and batteries in peace routine would have to be rather above war strength than below it. The Yeomanry require working up to be real Reserve to the one, and the Volunteer Field Artillery to the other; these remarks also apply in their main idea to R.E., A.S.C., and R.A.M.C. units.

Now that the Royal Regiment of Artillery has once been broken up, it seems desirable to take the further step here advocated to admit of the field units being made territorial and more readily org inised and mobilised. The coast-defence gunners should be made still more distinct and worked by a separate department at Head Quarters, but coming from them should be units of siege and mountain artillery selected as at present.

A Midland or Northern arsensal would supply stores for the Northern and Irish ports.

Nothing in the above scheme refers to mobilisation for home defence, but all tends to simplify that process rather than complicatc it. An efficient $\mathrm{Navy}$ should make that always a secondary consideration. Similarly, Sir John Colomb's scheme for the garrisons of the coaling stations would tend to help the general idea.

At present the similarly constituted and formed Colonial forces must depend on the goodwill of the Colonies to fall in with the scheme, and must continue to do so until some measure of federation becomes law.

The staff of the Reserve divisions would be appointed in time of peace from officers serving in the divisional command, and these should hold their appointments during the Xilitia and other mancuvres, and be prepared to drop into their places on mobilisation, and special service officers will be similarly detailed.

Musketry and artillery practice has not been referred to, but more attention would be paid to them than at present if territorial practice ranges were available, and these would help the- training of Militia, Reservists, and Volunteers.

To the Militia more pay and more attention must be given, and they must all be liable for forcign service.

Yeomanry and Volunteers must be distinctly divided regimentally into those willing to serve abroad on active service, and those who are only available for home service. No corps should be allowed to exist which does not provide a certain fixed proportion available for service with an expeditionary force. This means an extra cost again, for these corps will require more encouragement to keep at their proper strength. 
It is also to be hoped that this encouragement will bring a higher class into the ranks and more applicants for commissions. An exception to the foreign service rule might be made for Fortress Volunteers, whether artillery, engineers, or infantry.

The scheme does not claim to be an economical one, but the war has already cost $£ 85,000,000$, much of which might have been saved had the military forces of the Empire been more trained for their task; the cost of the Napoleonic wars has been already referred to. The greater assurance money brings even in peace some pecuniary return, for trade undoubtedly flourishes better with the greater fegling of security.

A loan would be required for the provision of barracks for the territorial regiments of cavalry and artillery; the enlargement of depotts for the infantry battalions; and for the provision of brigade camps of exercise and of divisional practice grounds; and for new arsenals and increased mobilisation stores. As compared. with the before the war estimates of 1899-1900, for the pay of the Army we should want about $£ 3,000,000$ extra-for Militia, $£ 400,000$; Yeomanry, $£ 100,000$; Volunteers, about $£ 500,000$; and for the other miscellaneous, items about $£ 5,000$;000 more, bringing the Estimates up to about $£ 30,000,000$; this. with the interest on the loan, would not be more than $15 \mathrm{~s}$. per head of the estimated population-a light burden as compared with conscription, and would give us a ıcally efficient Service.

The total personinel asked for is scarcely in excess of what we have at present, but from each branch of the Service a higher degree of efficiency is required; if we want a good thing-and we do want a good Army-we must pay for it, and apparently the country is quite willing to do this.

The terms of enlistment do not seem to require alteration, but no recruit should be taken for the Regular Army without a certificate of character and a birth certificate. The first will stop much of the present wastage by desertion, ctc., the second will ensure the recruit to be of full age. Both would lessen the number of recruits under the present terms, but the wages must be raised till a sufficient number do come in, for only so can we get an efficient Regular Army. 'Ihe better class of men will rcnder their obtaining employment as Reservists more simple; and the fact that men, if medically fit, can continue in thé Royal Reserve until they earn a pension, will help the soldier : 11 his days.

Has it been made clear that the Royal Reserve would be composed of men who had completed their first twelve years' service, either with the colours or in the Reserve, would be in second line to the ordinary Reserve, and would replace the present Section $D ?$ They would ré-engage for this service up to fifty years of age on very much the same lines as the reserve now being formed for the Navy and Marines. They would have to go through artillery or musketry practice and manœuvres when called upon. 'There would thus be four levies of Reserve ; first, under two years from the colours; second, remainder of the 1st Reserve; third, Royal Reserve-men under forty years of age ; and last, Royal Reserve under fifty ; but no Militia Reserve, or rather, all the Militia and part of the Volunteers 
and Yeo nanry would also be in Reserve for service abroad; the numbers of these and the levies to which they belong being worked out territorially under the G.O.C. the division. If the numbers of the Militia and foreign service Volunteers and Yeomen in any district do not come up to a fair proportion, it is then and then only that conscription should be talked of for that territorial division, or a money fine might be inflicted to pay for extra forces; but it is a practical certainty that local patriotism might always be called on to avoid this slur. The case of the Irish Division is a special one, but judging from the war, the time has arrived or is arriving when Ireland can'be treated on the same footing as the rest of the Kingdom, if not, it is a fine training ground for the English units which would be detached there-from time to time and which would form the details and line of communication troops of expeditions.

Lastly, we come to the provision of good and well-educated officers. It is quite part and parcel of the scheme that we should have a very large list of Reserve officers of all ranks, and that they shall know exactly in time of peace to which levy and which unit they belong on mobilisation. For the provision of these, the G.O.C. of the territorial division will be responsible, but delegating in some degree the work to officers commanding brigades and regiments; and he will see that there are officers enough for all the units after the Reserve levies' staff and special service officers have been withdrawn. Fortress commandants will have the same responsibility as regards coast-defence commands at home and abroad. To provide these cxtra numbers there is only the same suggestion as for the men, extra pay according to knowledge and ability in the profession.

Woolwich and Sandhurst will provide as many as they can be rendered capable of, and it would be a distinct improvement if the State could manage to give a free education at these establishments; then to reject all cadets during the courses who do not seem likely to make really hardworking and efficient officers, or at any rate to only give them Reserve commissions. With the free education, this would be no hardship on the idlc or backward cadet. In any case, this system will only provide a small proportion of the officers. The remainder, whether for Regulars, Militia, or Reserve (and perhaps for Yeomanry and Volunteers), will be appointed to a territorial regiment by the nomination of its colonel, the G.O.C., or the War Office, but with only medical examination, their general education being certified by Universities and schools. After a recruit's course in the regiment they will go through a garrison class (or War School), of which there will be one in every district and fortress. It is the same localisation and decentralisation idea as for the rest-of the scheme. Age of the nominees would be a secondary matter, so lons as they were between eighteen and thirty. All the officers, whether from cadet schools, or belonging to Militia and Reserves, will be on the same territorial regimental list and be promoted from the list in turn or by selection, merely being distinguished from one another by the letters on the shoulder-“ II" for Militia-" $R$ " for Reserve-(and perhaips " $V$ " for Voluntecers and " $\mathrm{Y}$ " for Yeomanry). At the end of the War School course in military subjects it will be determined by marks given in the 
course, by examination at the end, by the wish of the candidate, and by the approval of his colonel, to which branch of the regiment the candidate is posted, i.e., whether active; " II" or " R." All officers will get marks for a gymnastic and riding course; infantry for a school of musketry, artillery for a school of gunnery, and engineers for an engineer school course. After this test promotion examinations should not be required, but on promotion to each successive rank a lack of efficiency as pronounced by a promotion board will cause the officer to pass respectively from the active list of his regiment to the Militia, or from the Militia to the Reserve. This rule will apply equally to the officers from the cadet schools, who do not go through the War School examination. Active officers may be transierred to the Militia, or from the Militia to the Reserve at their own request; conversely, an extra display" of zeal in an " $\mathrm{MI}$ " or " $\mathrm{R}$ " officer may cause his selection for promotion to the active list. Efficiency will be judged by the much harder work with their men required of officers under the new system. Non-commissioned officers may be recommended for the Wrar School course, or may, for exceptional services, be promoted without it.

It is a scheme very like the German one, but, for all that, adapted to English ideas, very bad to beat for obtaining a really hard;working class of professional officers. The wealthy man who wishes to serve the State, and would like a little fighting and a little soldiering, but wants a lot of leave and doès not like the dull regimental grind, will find what he wants in the Militia and Reserve; and there will not be the same apparent hardship in refusing a step on the active list to an incapable officer, for he will get his step all right on the reserve list, that is, if he is worth even that promotion. Pay and retirement must be graduated in the different classes to suit the market as regards supply and demand..

The Staff College finds the same place in this scheme as in our. present one, cxcept that every graduate will know his place on the territorial staff directly after passing; and if it is not an active appointment, will seek to qualify for it while performing his actual regimental duties.

Now to sum up, the advantages claimed for the reform as a whole are :-

1. It provides a real territorial syste. 1. Men will always return to their own neighbourhood for their trainung service, and there will be a real link between the different parts of a division, and with the MIilitia, Yeomanry, and Volunteers.

2. On general mobılisation for either Service at home or abroad, everything will be decentralised, and Reserves, etc., will find their depots and mobilisation stores close at hand'. Provision is made for the organisation of the whole military resources of the nation to the last man who has hanaled a rifle in time of peace.

${ }^{1}$ Actire commiissionis would only date from completion of - War. School caurse,so 2 , to be fair to.calets:

vol. XLV. 
3 There would be a real and properly graduated system of training from the company to the division, and officers will be able to take a real interest in their men; and havingpersonally taken the unit under their command through at lcast one year's complete course, can be judged, not by promotion examinations, but by the efficiency of the men they have trained.

4. Territorial brigades and divisions on active service will have a real esprit de corps which South African experience has shown can have a great effect on efficiency.

5. Perhaps, most important of all, the higher staffs can work together in peace and prepare quietly and efficiently for their duties in war; and whatever failure there is in their units in war will be mainly due to them, and to them alone, and so the blame for failure can be placed on the right shoulders. From South African experience this is of real and immense importance.

6. The scheme will fit in with any measure of Imperial Federation which may hereafter be passed, and until such a measure is passed there does not seem to be much advantage in devising schemes for Colonial use; we can only set the good example of putting our own house thoroughly in order and ask them to follow the lead.

These, then, are the details and claims of a scheme which essays, however feebly, to remove some apparent defects of our organisation. That it still leaves much to be said must be obvious, since it suggests nothing that will stop the guerilla warfare still raging in South Africa, since it provides no cure for the fact that we are still out-marched by our opponents, that we are still over-matched in strategy by these." simpleminded" farmers. It does not tell in the future how to avoid the enormous outlay incurred in the purchase of 200,000 horses and mules (perhaps the motor-car will help us in this detail); it gives no settled plan for an improved Indian or Colonial Army; above all, it does not lay before a perplexed Chancellor of the Exchequer any system by which our enormous expenditure can be reduced, but. ither advocates an increase (income-tax paying officers will regret this equally with civilians). In short, its author feels.its shortcomings as much as can any of its critics.

The closest study of the subject has shown no great organiser who was alive to our imperfections before the event; or no great general or statesman at home or abroad who had suggested better plans than ours, or could have provided braver soldiers to carry them out. Still, our errors are glaring now, and it is better for a nation to be wise afier the event than never to be wise at all! The Empire, and, above all in this matter, the Army, is seeking earnestly to remove such flaws as there are, and from such earnest search (may it long continue earnest!) much good must result. - Let us trust that the military lessons of this trying year may serve the Empire in its next great hour of need, and that then there may be the same soundness in the heart of the people and the same 
glorious loyalty in the Colonies, and one can only conclude with the motto selected "Spero meliora."

APPENDIX I.

TIE First ReINForcesievts fROM INDIA.

\begin{tabular}{|c|c|c|c|c|c|c|}
\hline Name of Unlt. & & Embarkation. & Date. & Transport. & Arrired. & Date. \\
\hline 5th Dragoon Gua & $\ldots$ & Bombay $\quad .$. & 26 Sept. & $\begin{array}{l}\text { "Lindula " } \\
\text { " Warlha " }\end{array}$ & $\begin{array}{l}\text { Durban } \\
\text { Canc }\end{array}$ & 12 Oet. \\
\hline 9ri Lancers ${ }^{2} \quad \ldots$ & $\ldots$ & Bombay $\quad .$. & 21 Sept. & $\left\{\begin{array}{l}\text { "Nowshera" } \\
\text { " Nairmog" } \\
\text { "Yaula" }\end{array}\right.$ & Cape & 11 0̣ct. \\
\hline 19 th Hussars $\ldots$ & $\ldots$ & Bombay & $2 \&$ Sept. & $\left\{\begin{array}{l}" \mathrm{Si} \\
" \mathrm{~W}\end{array}\right.$ & $\begin{array}{l}\text { Durban } \\
\text { Durban }\end{array}$ & $\begin{array}{l}5 \text { Oct. } \\
5 \text { Oct. }\end{array}$ \\
\hline
\end{tabular}

Brigade Dicision R.F.A.

\begin{tabular}{|c|c|c|c|c|c|c|c|}
\hline $\begin{array}{l}\text { 21st R.F.A. } \\
\text { t2ud R.F:A. } \\
\text { o3rol R.F.A. }\end{array}$ & $\cdots$ & $\begin{array}{c}\cdots \\
\cdots \\
\cdots\end{array}$ & $\begin{array}{l}\text { Bombay } \\
\text { Bombay } \\
\text { Bonbay }\end{array}$ & $\begin{array}{l}\cdots \\
\cdots \\
. .\end{array}$ & $\left|\begin{array}{ll}18 & \text { Sept. } \\
18 & \text { Sept. } \\
19 & \text { Scpt. }\end{array}\right|$ & $\begin{array}{l}\text { "Lalpoora"- } \\
\text { "Secundm". } \\
\text { "Booldana"- }\end{array}$ & $\left|\begin{array}{c}\text { Durban } \\
\text { Durban } \\
\text { Durban }\end{array}\right|$ \\
\hline
\end{tabular}

Infantry Brigadc.

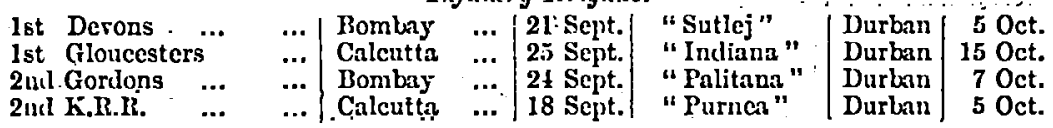

Frour JediterranedN ard HoNe.

Infautry Brigaide.

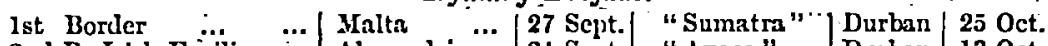

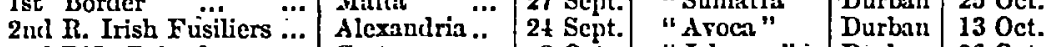

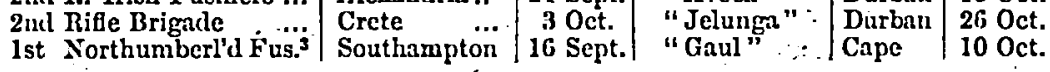

Brigaté Dicisioñ R.F.A."

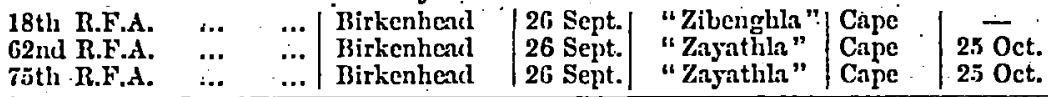

REMARKS ON ABOTE TABLE.

2 Only one squalion of the 5th Dragon Guards was able to leare at the proper time, the remainder being delnyed bj" an outbreak of anthrix until 8tli October.

2 The 9th Lancers haring reached Durban were seut round to the Cape.

3 The 1st Battalion Northumberland Fusiliers,- although taking part in the Salisbury Plain manourres and receiving orders at Aldershot, were really on the Foreign establishment, and had only just been brought home to accruit after the fatigues of Omdurman and Crete.

- This brigade division did not hare a pleasant trip; the "Zibenghla" was still in the Mersey on 2nd October, haring been deliyed by defects of mnchinery and an outbreak of fire in her coal bunkers. The "Zajathla" duly left Birkenheal oil the 29th September, but had to put into Qucenstown to refit, having lenking boilers, but she left a day or two later. Of course both these ships were carefully inspecterl by the usual boards of officers both before and after they were fitted as troop-ships. New furnaces harl been supplied to each, and they had, been pronounced in excellent condition. Eventually they arrirel at Cape Town rery little orcrdue, though the fate of the un. fortunate ganners was the subject of much discussion at home during the periol between their departure and arrival.

The troops from India had sailet complete in transport, equipment, and with feld hospitals, bearer companies, and ammunition columns, but no native camp followers werc allowed. Howerer, for general supply three Army Serrice companies, one ordnance company, an ammunition column, and extm horses were sent out from hoire at the same time. 
APPENDIX ' II.

The Colonial Troops.-The Cate Colont.

Name of Corps.

Cape Colony Volunteers

Oape Town Highlanders

Prince Alfral's Omn Artillery

Cape Garrison Artillery...

- Griqualañal West Brigadè

Diamond'Fields Artillery

Kimberley Regiment ...

Transkei Mounted Rifles

Eorngha Mounted Rifles

Duke of Ediniburgh's Orn

Prince Alfred's Guards ...

First GraLamstown Volunteers...

Queenstown Volunteer Corps .

Kaffrarian Rifles...

Western Rifles

$\cdots-\cdots$

Kinysa Rangers ... ...

Uitenhaga Rifles....

Bechuanaland Rifles

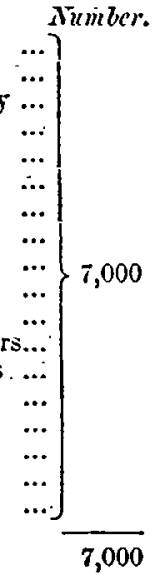

Name of Curps.

Cape Mounted Rifles $\quad \ldots \quad \ldots 1,000$

Cape Mounted Police $\quad \ldots \quad \ldots 2,000$

Protectorite' Regiment $\quad \ldots \quad \ldots \quad$ 500

Brabant's Horse ... $\quad \ldots \quad \ldots 1,000$

Rimington's Güides $\quad \ldots \quad \ldots \quad 150$

Nesbitt's Horse $\quad \ldots \quad \ldots . \quad \ldots \quad 500$

Bayley's Morse $\quad \ldots \quad \ldots \quad \ldots \quad \ldots \quad 500$

South African Light Horse $\quad \ldots \quad 8.50$

$\begin{array}{lllll}\text { Roberts' Horse } & \ldots & \ldots & \ldots & 850\end{array}$

Kitchener's Horse $\quad \ldots \quad \ldots \quad 850$

Pioneer Railway Corps $\ldots . . \quad \ldots .1,200$

Diamond Fields Horse $\quad \ldots \quad \ldots \quad \ldots \quad 800$

Kimberley Light Horse $. . . \quad \ldots . \quad . \quad 800$

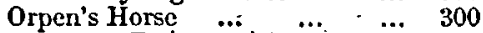

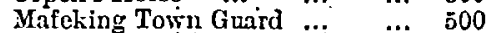

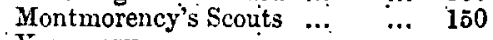

Yeomanre ...

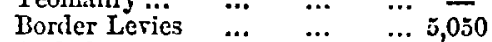

Ambulance Bearers . ...

\section{$\begin{array}{lllll}\text { Grand Total for Cape Colony. } & \ldots & \ldots & 24,000 .\end{array}$}

NATAL Forces.

$\begin{array}{lccrr}\text { Mounted Police } & \ldots . . & \ldots & \ldots & 649 \\ \text { Imperial Light Horse } & \ldots & \ldots & 1,000 \\ \text { Imperial Light Infantry... } & \ldots & 1,000 \\ \text { Bethune's Mounted Infantry } & \ldots & 500 \\ \text { Thorneycroft's Mounted Infantry } & 500 \\ \text { Murray's Horse } & \ldots & \ldots & \ldots & 500 \\ \text { Warren's Horse } & \ldots . & \ldots & \ldots & 500 \\ \text { Colonial Scouts } & \ldots & \ldots & \ldots & 500 \\ \text { Ambulance Bearers } & \ldots & \ldots & \mathbf{1 , 6 0 0} \\ & & & & \mathbf{6 , 7 4 9}\end{array}$

Grand Total for Natal
Natal Volunteers

Royal Rifles $\cdots$...

Naral Volunteers $\quad \cdots$

Durban Light -Infantry

Carbineers

Border Mounted Rifles

Field Artillery.

Mountèl Rifles.

Newcastle Rifles

Umroti Rifles

.. $\quad \ldots \quad 8,749$.

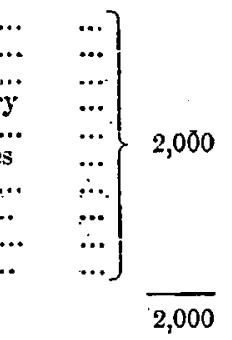

AUSTraliak Coxtivaests.

NEW ZEALAsid, in four contingents and one of Busbmen, sent 1,816 .

\section{CANADA.}

\begin{tabular}{|c|c|c|c|c|}
\hline Infantry & & & & 1,000 \\
\hline Mounted Infantr & $\because$ & $\ldots$ & & 727 \\
\hline Brigade Dirision & Field & Artillery & & 537 \\
\hline Rough-riders & ... & ... & . & 520 \\
\hline & Gran & Total & ... & 2,784 \\
\hline
\end{tabular}

INDIA sent Lumisden's Horse numbering 250 men, and CerLox - added a small contingent' 130 strong.

W'e thus obtain a total from the Colomes of 44,230 men, and nearly 40,000 horbes tuough it should tot be forgotten that the expense of the different Imperial Corps fell on the British taxpayer.

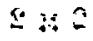


APPENDIX III,

Showing approximate positions of troops in South Africa on outbrcak of War, 11 th Oetober, 1899.

Natal Force.

At Dundee.

1st Iucicesters. lst K.R.R.

18th Hussars.

13th, 67th, and 69th R.F.A.

2nd Dublin Fusiliers.

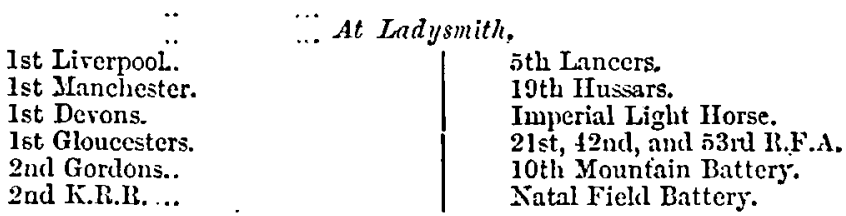

The Natal Police and Local Jounted Corps were distributed along the frontier; the 7th Fickl Company R.E., Stli Railway Company R.E., and the 23rd Ficld Company R.E. were distributed in Natal between places and units; there was a squadron of the 5th D.G. at Durban; - while the battalions of the R. Irish Fusiliers, Border Regiment, and Rifle Brigade were still at sen. H.II.S. "Powerful" was at Durban.

In Cape Colony.

1st Tiogal Munsters.

2nd. Berkshire.

1st Northumberland Fusitiers.

1st Loynl North Lancashire, half at Kimberley, with the 23rd Company R.G.A., and the 20th Company Fortress R.E. Half the Yorkshire Light Infantry were at De Aar, half were in the "Powerful" at Durban, the 9th Iancers were wandering between the two Colonies; there were further the Cape Colony Corps and Police; another company of Garrison Artillery, while a brigale of Marines and Bluejackets which had been landed had just re-embarked"; the 18th, di2nd, and 75 th Ficld Batteries were still at sea. $\dot{A}$ t Mafeking were the Rhodesian forees, and there was another forec of police at Tuli.

Not 20,000 men in the whole two Colonies!

... APPEXDIX IV.

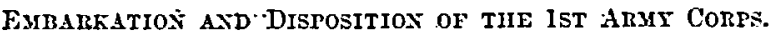

\begin{tabular}{|c|c|c|c|c|c|c|}
\hline Name of Unit. & $\begin{array}{c}\text { Port of } \\
\text { Embarkation. }\end{array}$ & Date. & Transport. & Arrived. & Date. & Final Disposal. \\
\hline G.O.C. \& Staff & ... Southampton & ... Ifth Oct. & 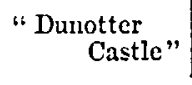 & Cape ... & 31st Oct. & Natal. \\
\hline \multicolumn{7}{|c|}{ Cacalry Dixision_-Frencli: } \\
\hline Staff & Southampton & 20th Sept. & - & - & - & $\begin{array}{l}\text { Colesberg } \\
\text { District. }\end{array}$ \\
\hline
\end{tabular}

1 st Brigadc-Babington.

\begin{tabular}{|c|c|c|c|c|c|c|}
\hline Staff & $\begin{array}{l}\text { London : } \\
\text { R Albert Dks. }\end{array}$ & 23 rd Oct. & 一 & Cape & 16tli Nov. & To French. \\
\hline wth Dragoon Gds. & $\begin{array}{l}\text { London : } \\
\quad \text { R. Albert Dks. }\end{array}$ & 8th Nor. & $\begin{array}{l}\text { "Chicago" } \\
\text { "City of Persia" }\end{array}$ & Cape & 1st Dec. & $"$ \\
\hline 10th Hussars & Liverpool ... & $\begin{array}{l}\text { 4th Nov. } \\
\text { 8th Nor: }\end{array}$ & "Ismore" ". & $\begin{array}{l}\text { Cape ... } \\
\text { "Ismore" } \\
\text { wreckel }\end{array}$ & 2nd Dec. & $"$ \\
\hline 12th Lancers & $\begin{array}{l}\text { London : } \\
\quad \text { R. Albert Dks. }\end{array}$ & 23 ral Oct. & $\begin{array}{l}\text { "Mohawk" } \\
\text { "C.of Vicnna" }\end{array}$ & & & To Meth \\
\hline
\end{tabular}




\section{APPEXDIX IV,-continued.}

2nd Brigade-Brabazon, who went to Imperial Yeomanry.

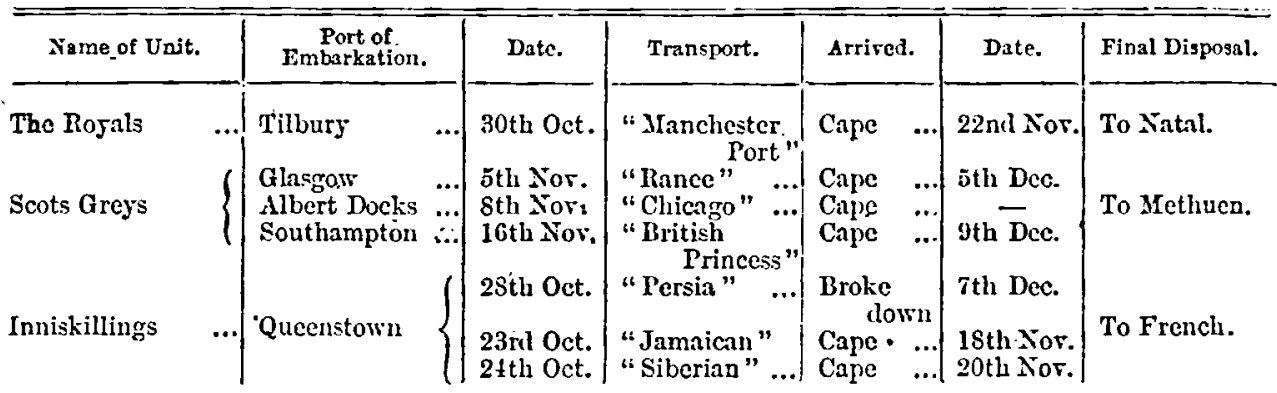

Brigade Dixision R.II.A.

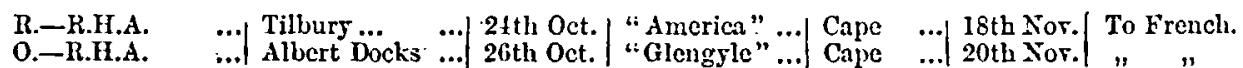

\section{Mounted Infantry.-1st Battalion.}

S. District Co. Aldershot Co. S.E. Co. .... Cork Co. ...

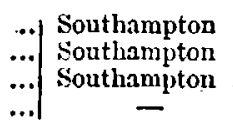

\section{3ri Oct. "Yaita"}

\begin{tabular}{|c|c|c|c} 
23rd Oct. & "Malta" & Cape \\
23rd Oct. & "Malta". & ... & Cape \\
23rd Oct. & "Aurania" & ... & Cape \\
\hline & Aurania" & ... & Cape
\end{tabular}

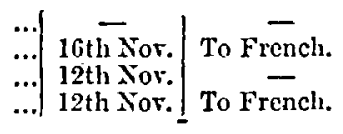

2nd Battalion.

Yorthern Co. Western Co. Dublin Co. Eastern Co.

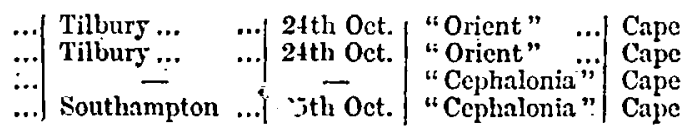

1st. Infantry Dirision-Lord Methuen, who went to Kimberley. 1st Brigade-Colvile. The Guards.

\begin{tabular}{|c|c|c|c|c|c|c|}
\hline 3rd Gre & Gibraltar & $26 \mathrm{tl}$ & "Goorkha" & - & 15th Nor. & To. Methuen. \\
\hline 1st Coldst & Gibraltar & 28th Oet. & "Malta" ... & - & 16th Nov. & \\
\hline 2nd Coldstrcams.. & Southampton & 2 lst Oct. & "Gascon" & & 12th Nor. & "1 \\
\hline $10+\mathrm{S}$ ot & Southampton & $21 s$ & "Nubin" & & 13th Nor. & $\dot{ }$ \\
\hline
\end{tabular}

2nd Brigade-Iildyaid.

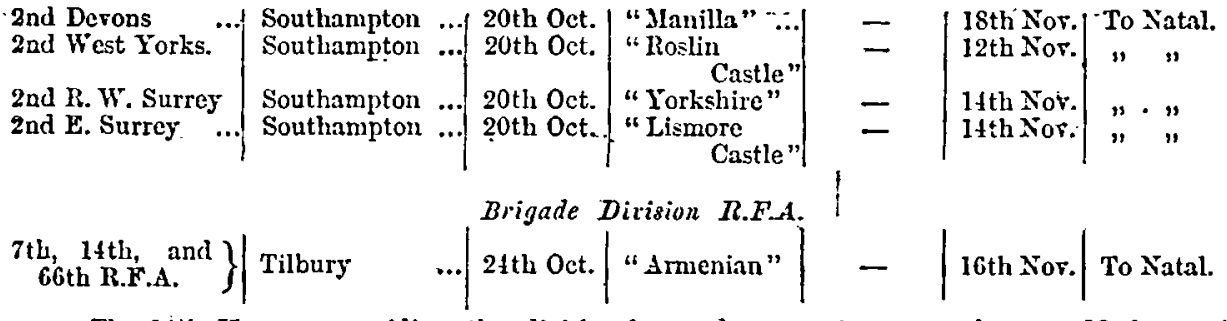

The 14th Iussars, provicling the dirisional squadrons, sent one squadron to Methuen, the remainder landed at Durban on the 7 th January.

\section{2nd Infantry Division.-Clery, who ment to Natal.}

$$
\text { 3rd Brigade-Highlanders.-Wauchope. }
$$

2nd Black Watch / Tilbury ...

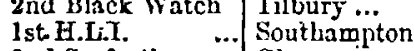
2nd Senforth ... Glasgow Ist A. \& S. Highrs. Q Quecnstown

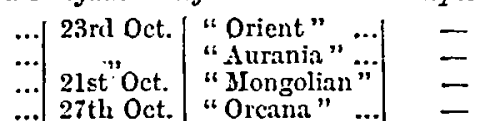

11th Nor: To Methuen. 11tl Nor, " " 18th Nor: " " 
APPENDIX IY.-continued.

4th Brigade-Rittes.-Lyttelton.

\begin{tabular}{|c|c|c|c|c|c|c|c|}
\hline Name of Unit. & $\begin{array}{c}\text { Port of } \\
\text { Emlarkation. }\end{array}$ & & Date. & Transport. & Arrived. & Date. & Final Disposal. \\
\hline Ist Durham L.I. ... & Southampton & ... & 24th Oct. & "Cephàlonia" & - & 23rd Nör. & To Natal. \\
\hline 2nd Cameronians & Glasgow & 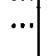 & 23ril Oct. & $\begin{array}{l}\text { "City of } \\
\text { Cambridge" }\end{array}$ & - & 21 st Nor. & \\
\hline 3rd K.R.R. & Queenstown & $\cdots$ & 5th Nor. & "Servian" ".. & 一 & 30th Nor. & $"$ \\
\hline Ist Rifle Brigade... & Soutinampton & & 2Sth Oct. & "German" ... & $\longrightarrow$ & 25th Nor. & $"$ \\
\hline
\end{tabular}

\section{Brigade Division.}

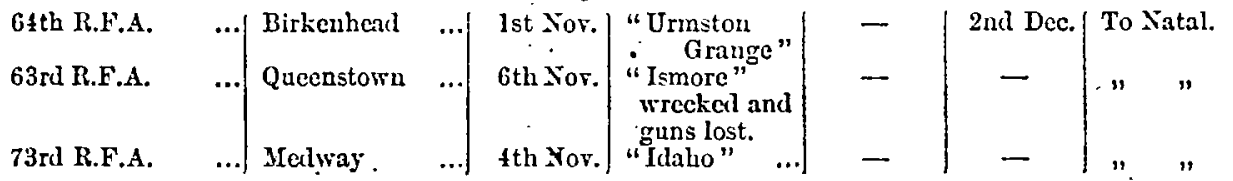
3rd Infantry Division-Gatacre, who went to Stormberg.

5th Brigade.-Irish.-Wart.

1st Inniskilling Fus. Queenstown 2nd R. Irish Ihifles Queenstown lst Connaughts ... Quecustown

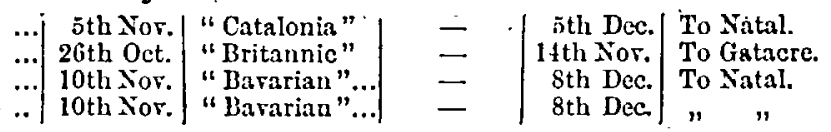

,6th Brigade.-Fusiliers.-Barton.

\begin{tabular}{l|l|} 
2nd R. Irish Fus.... & Southampton.... \\
2nd R. Fus. & .. \\
2nd R. Scots. Fus. & $\begin{array}{l}\text { Southampton } \\
\text { 1st R. Welsh Fus. }\end{array}$ \\
Soutbampton
\end{tabular}

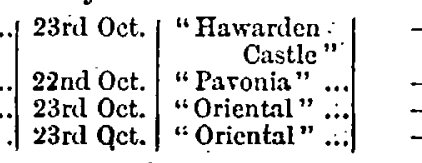

Brigade Dirision.

77 th R.E.A. 7 th R.F.A. 79th R.F.A.

$$
\begin{array}{l|l}
\text {... } & \text { Liverpool } \\
\text {... } & \text { Liverpool } \\
\text {... } & \text { Quicenstow }
\end{array}
$$
... 3rd Nor. "Englishman"|

\section{Corps Troops.}

13 th Husears

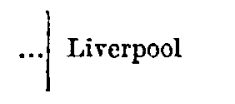
... 10th Nor. $\left\{\left\{\begin{array}{c}\text { "Temple- } \\ \text { more" " Montfort" }\end{array} \mid\right.\right.$ Brigade Dirision R.M.A.

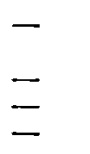

$\mid$\begin{tabular}{l|l|l} 
isth Nor. & To Natal. \\
$23 r d$ Nor. & \\
2Ist Nor. & $" 1$ \\
21st Nor. & $"$ & $"$
\end{tabular}
P.-R.H.A. G.-R.H.A. \} Birkenträd

..| 30th Oct. " "Pindari" ....

Brigade.Division R. F. A.

78th R.F.A. 38th R.F.A. th.R.F.A. 13th Nor. "Sicilian"

7th Nov: "Algeria",<smiles>CC(C)C1CC1</smiles>

\begin{tabular}{c|l|l}
$\ldots$ & R. Albert Docks \\
$\ldots$ & Chatham & Chathen \\
$\ldots$ & Southampton &...
\end{tabular}

\section{IIowitier Brigade. Division.}

6i)th R.F.A. Glst R.F.A. 37th R.F.A.
... 1R.: Albert Docks |

... Liverpool ... Southamptón 12th Nor. "Cannitig". 11th Nor. "Montfort.;"... \begin{tabular}{l|l|l} 
- & 30th Nor. & To Gatacre. \\
30th Nor. & $"$ & $=$
\end{tabular}

- $\}$ jtb Dec. To Natal.

- $\quad$ 25th Nor. To Methuen.

- $\quad 14$ th Dec. To Natal. - 5̃th Dec. Tó Methuen. 14th Dec. To Natal.

4th Dec.] To Methuen. Sth Dec. To Natal.

Ist Royal Scots ... Quecristown ... Gth Nor. $\mid$ "Dictator" ...

Similarly the Line of Communication troops were rariously distributed, and found themselres at once in the first fighting line. They cmbarkel in ten troop-ships between the. 20th October and the 9th Norember. 